\title{
(1) Nordregio
}

\section{Transition to a bioeconomy in Northwest Russia}

Regional cases of the Republic of Karelia and Murmansk oblast

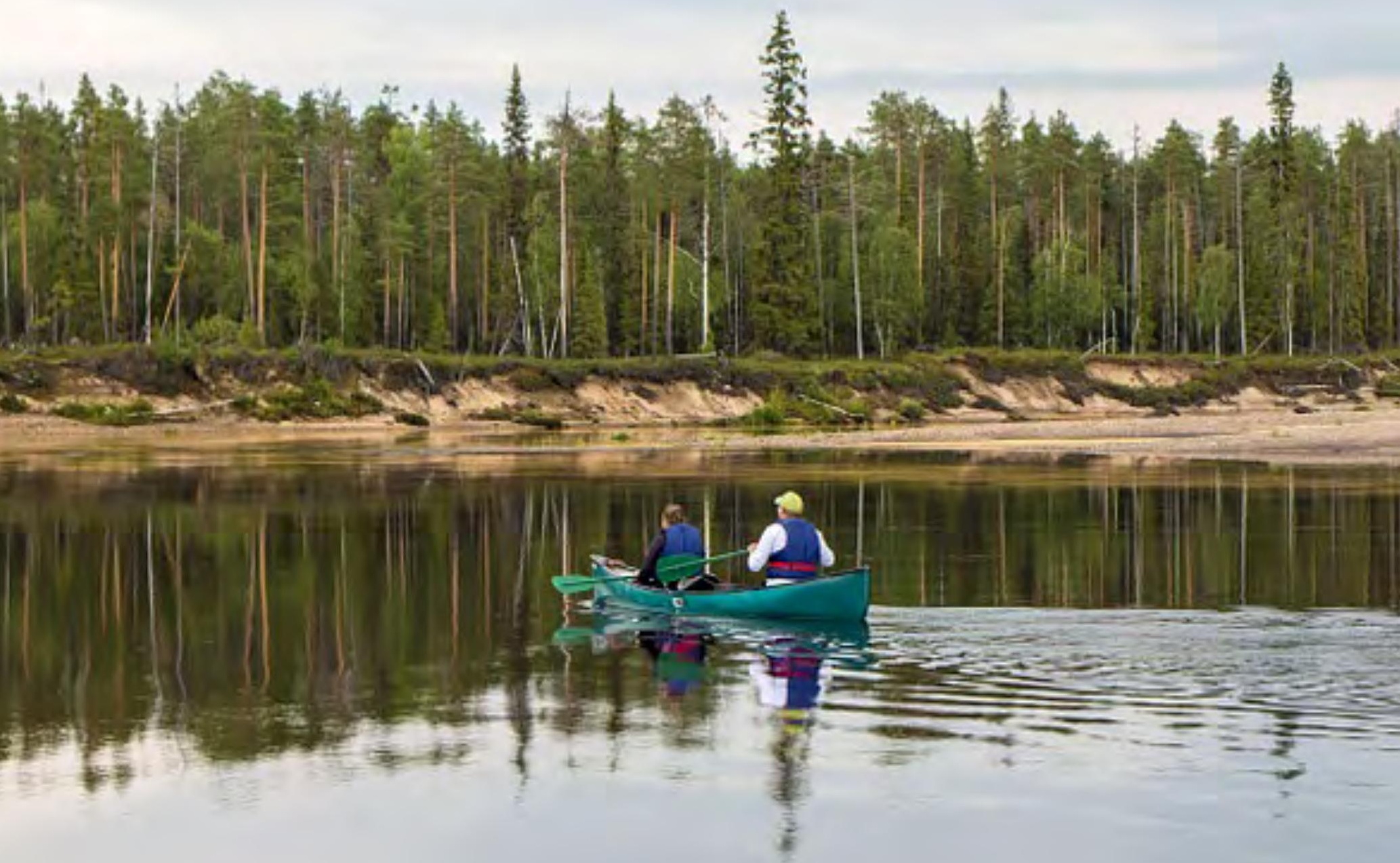

By Anna Berlina \& Alexey Trubin

NORDREGIO REPORT 2019:10 



\section{Transition to a bioeconomy in Northwest Russia}

Regional cases of the Republic of Karelia and Murmansk oblast

By Anna Berlina \& Alexey Trubin

NORDREGIO REPORT 2019:10

Prepared on behalf of the Nordic Thematic Group for Innovative and Resilient Regions 2017-2020,

under the Nordic Council of Ministers Committee of Civil Servants for Regional Affairs. 
Transition to a bioeconomy in Northwest Russia:

regional cases of the Republic of Karelia and Murmansk oblast

Nordregio Report 2019:10

ISBN: 978-91-87295-76-8

ISSN: $1403-2503$

DOI: doi.org/10.30689/R2019:10.1403-2503

(C) Nordregio 2019

Nordregio

P.O. Box 1658

SE-111 86 Stockholm, Sweden

nordregio@nordregio.org

www.nordregio.org

www.norden.org

Analyses and text: Anna Berlina \& Alexey Trubin

Contributors: Vera Meshko, Alla Shishalova, Mads Randbøll Wolff, Anton Shcherbak and Karen Refsgaard

Cover photo: Pixabay

This project is funded by the Nordic Council of Ministers (NCM). In this project, the geographic focus is on the Murmansk oblast and the Republic of Karelia within the bioeconomy. It is a continuation of the NCM-funded project 'Nordic-Russian bioeconomy pre-study' that focused on bioeconomy in Arkhangelsk oblast in Russia.

\section{Nordregio}

is a leading Nordic and European research centre for regional development and planning, established by the Nordic Council of Ministers in 1997. We conduct solution-oriented and applied research, addressing current issues from both a research perspective and the viewpoint of policymakers and practitioners. Operating at the international, national, regional and local levels, Nordregio's research covers a wide geographic scope, with an emphasis on the Nordic and Baltic Sea Regions, Europe and the Arctic.

\section{The Nordic co-operation}

Nordic co-operation is one of the world's most extensive forms of regional collaboration, involving Denmark, Finland, Iceland, Norway, Sweden, and the Faroe Islands, Greenland, and Åland. Nordic co-operation has firm traditions in politics, the economy, and culture. It plays an important role in European and international collaboration, and aims at creating a strong Nordic community in a strong Europe. Nordic co-operation seeks to safeguard Nordic and regional interests and principles in the global community. Common Nordic values help the region solidify its position as one of the world's most innovative and competitive.

\section{The Nordic Council of Ministers}

is a forum of co-operation between the Nordic governments. The Nordic Council of Ministers implements Nordic co-operation. The prime ministers have the overall responsibility. Its activities are co-ordinated by the Nordic ministers for co-operation, the Nordic Committee for co-operation and portfolio ministers. Founded in 1971.

\section{The Nordic Council}

is a forum for co-operation between the Nordic parliaments and governments. The Council consists of 87 parliamentarians from the Nordic countries. The Nordic Council takes policy initiative $s$ and monitors Nordic co-operation. Founded in 1952. 


\section{Table of contents}

1. Introduction

2. Administration and governance in the Russian Federation.............................10

2.1 Forest management - institutional organisation........................................................................... 11

3. The bioeconomy in the Republic of Karelia ………………………………………....14

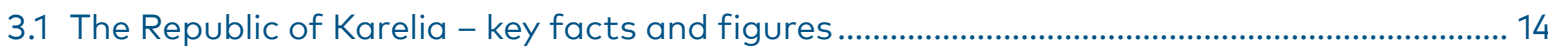

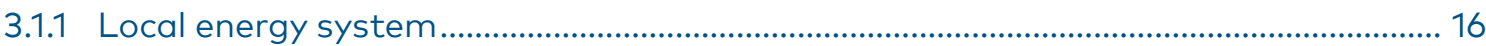

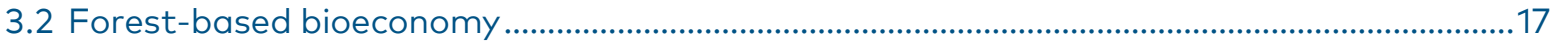

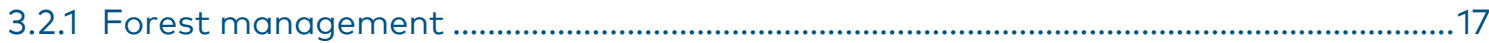

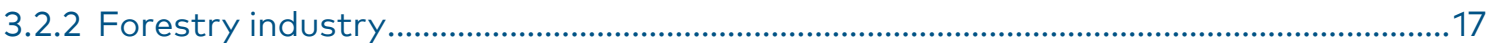

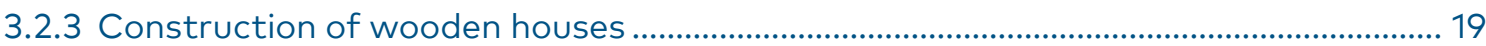

3.2.4 The use of other biological resources from forests........................................................... 20

3.2.5 Bioenergy production from forest-based residues ........................................................... 20

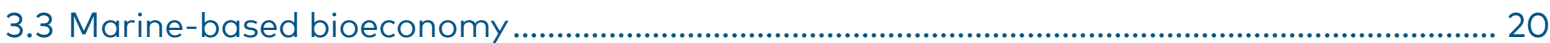

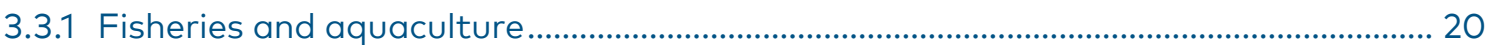

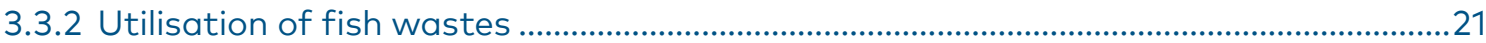

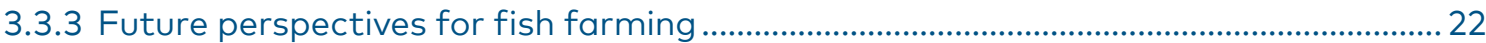

3.4 Policy framework and state support for the bioeconomy …..................................................... 23

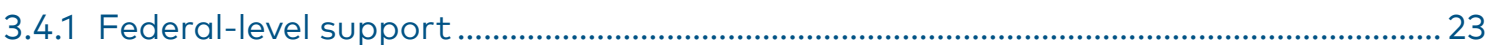

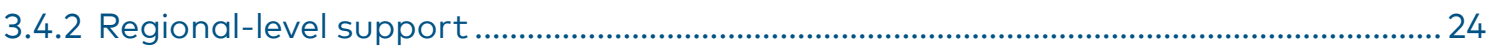

3.5 Educational and research institutions enabling the transition to a bioeconomy..................26

4. The bioeconomy in Murmansk oblast ......................................................................... 27

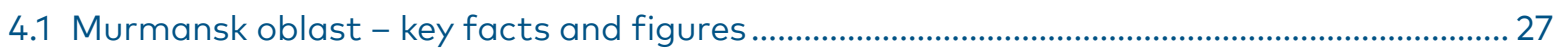

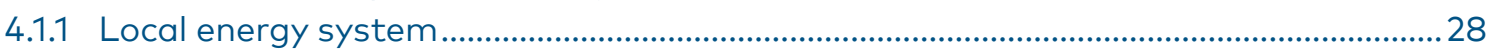

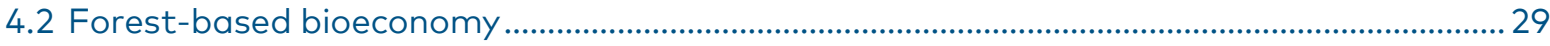

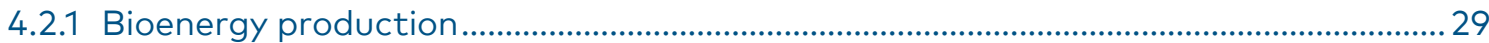

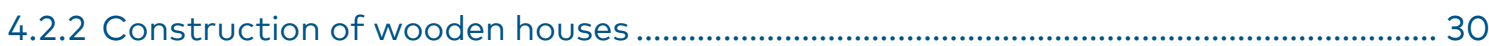

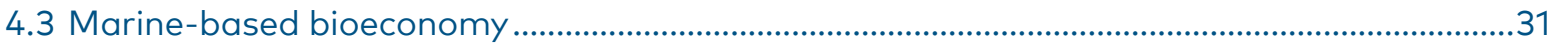

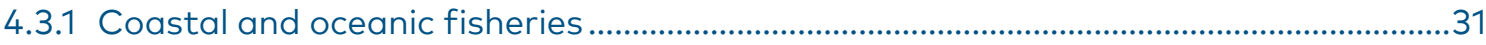

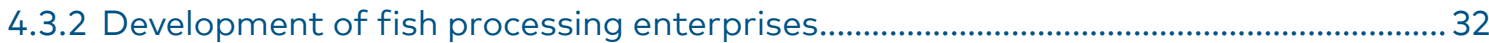

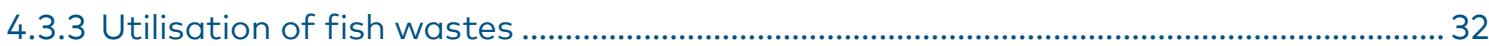

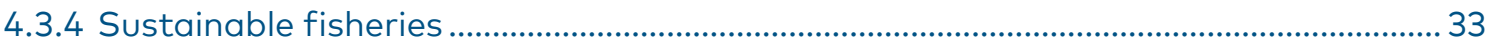

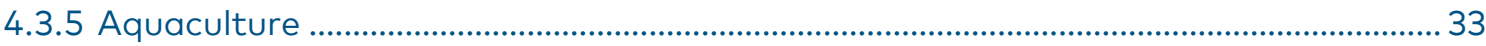

4.4 State support and the policy framework for the bioeconomy ..................................................33

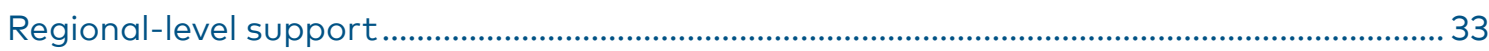

4.5 Educational and research institutions enabling the transition to a bioeconomy ..................34

5. Opportunities and challenges for bioeconomy development .........................36

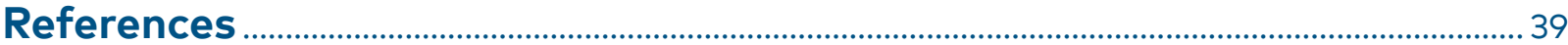


Figure 1. Institutional organisation of forest management in the Russian Federation.

Source: FAO, 2012

Figure 2. Breakdown of Karelia's economy in 2013 as a share of GRP, \%.

Source: PwC 2014 16

Figure 3. Production of forest industry products in the Republic of Karelia.

Source: PwC 2014 . .18

Map 1. Case study regions. Map by Eeva Turunen

Map 2. The location of the Republic of Karelia, its administrative centre, Petrozavodsk, and several companies involved in bioeconomic activities 14

Map 3. Map of Murmansk oblast and some companies involved in the bioeconomy

Table 1. Key facts and figures - Murmansk oblast and the Russian Federation.

Source: (Kareliastat, 2019; Rosstat, 2017, 2018) 15

Table 2. Aquaculture production in the Republic of Karelia. Adopted from Sterligova and Ilmast (2018) and (Stolica Onego, 2019).

Table 3. Key facts and figures - Murmansk oblast and the Russian Federation.

Source: (Rosstat, 2017, 2018) 


\section{Introduction}

The development of a bioeconomy is at the forefront of the national and regional agendas of many European countries given not only its potential to counter climate change through replacing goods and services currently produced using fossil fuels and other non-renewable resources, but also the new economic activities in and around the rural regions it stimulates (Refsgaard et al., 2018). However, there is relatively little known about the status and institutional and policy frameworks for bioeconomy development in Northwest Russia.

The purpose of this study is to provide a comprehensive overview of the status of and institu- tional framework for a bioeconomy in the Republic of Karelia and Murmansk oblast (see Map 1). The study identifies some of the main support mechanisms and incentives, as well as the potential and challenges, for bioeconomy development in these regions today and in the future. This study, which was financed by the Nordic Council of Ministers in 2018-2019, Kicking off the Bioeconomy in the North, draws upon the lessons learned from the study financed by the Nordic Council of Ministers in 2018, 'Forest and Waste-based Bioeconomy in the Arkhangelsk region' (Berlina and Trubin, 2018).

The main research questions are:

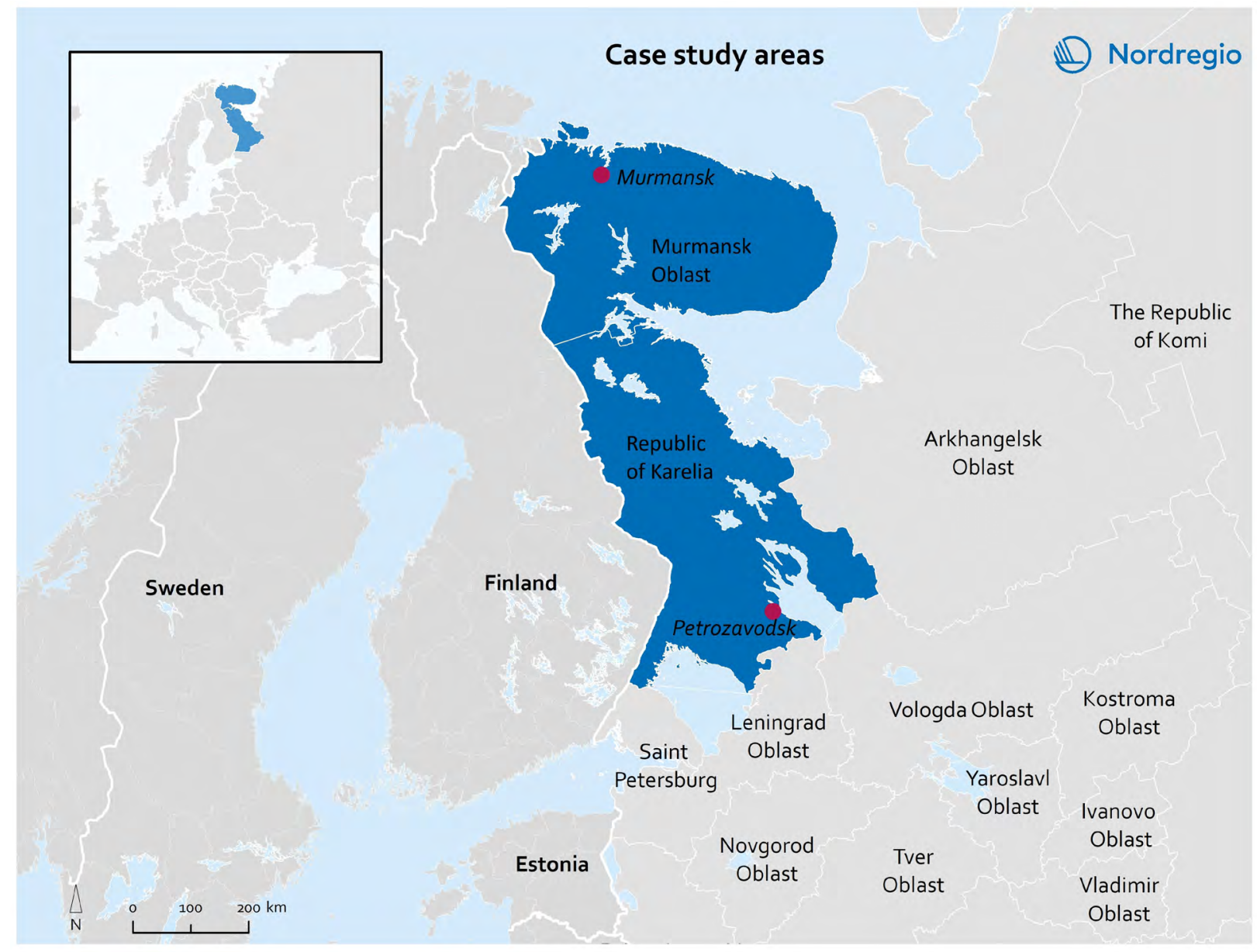

Map 1. Case study regions. Map by Eeva Turunen 


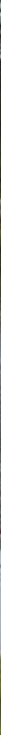

What is the status of forest- and marine-based activities in the Republic of Karelia and Murmansk oblast?

- What policy instruments and support measures are available to drive the forest- and marinebased bioeconomy agenda in Northwest Russia?

- What are the enabling conditions and impeding factors influencing the development of a bioeconomy from a regional perspective?

The study draws upon face-to-face interviews conducted with key actors involved in bioeconomy development in the cities of Murmansk and Petrozavodsk in July 2018 along with desk-based research. The actors interviewed included representatives from the regional authorities, businesses and nongovernmental organisations and academics work- ing in the forest- and marine-based bioeconomy field. The desk-based research draws on a review of relevant reports, policy documents, online news articles and academic publications, including both Russian and English language sources.

In terms of the limitations of the report, it is important to note that in some cases, it has been difficult to evaluate the quality and reliability of the information provided in the external sources and during communication with the interviewees; thus, attempts were made to provide neutral arguments and avoid biased facts by collecting information from different independent sources. However, there is a need for more extensive research so that deeper insights into the status, potential and challenges for a bioeconomy in Northwest Russia can be gained. 


\section{Overgang til en bioøkonomi i Nordvestrusland. Regionale casestudier i regionerne Karelien og Murmansk}

Bioøkonomien er på forsiden af regionale og nationale dagsordener i mange europæiske lande. Dette skyldes både potentialet for at møde klimaændringer gennem at erstatte fossilbaserede varer og tjenester med biobaserede, men også fordi bioøkonomien kan bidrage med økonomiske muligheder og arbejdspladser i landdistrikter og regioner. Nordvestrusland er i så henseende interessant med en lignende tilgang på bioressourcer som i de nordiske lande, men kundskaben om de institutionelle og politiske rammebetingelser er begrænsede. I denne rapport har vi undersøgt status og udviklingsmuligheder for bioøkonomien i Republikken Karelien og Murmansk Oblast i Nordvestrusland.

Den Karelske regions økonomi er afhængig af natur og ressourcebaserede industrier med muligheder for udvikling af bioøkonomien bl.a. p.g.a. de favorable agri-klimatiske forhold og fælles grænser mod EU med de markedsmuligheder det har. Tømmer, træforædling, pulp og papir industri og metalindustri er hovedsektorer. Der er også gode muligheder indenfor turisme, rekreation, mad, fiskeri og bioteknologisk industri. Murmansk er en industrialiseret region hvor minedrift, produktion af mineralsk gødning er de dominerende industrier. Indenfor primærsektoren er det især fiskerisektoren som er vigtig. Rapporten ser specielt på rammebetingelser og organisatoriske muligheder. Hovedkonklusionerne er primært rettet mod offentlige myndigheder og andre interesserede aktører som arbejder med bioøkonomi-relaterede emner på forskellige styringsniveauer og opsummeres her:

- Støtte iværksætteraktiviteter for unge professionelle og studerende gennem at fremme erhvervs- og højere uddannelser og knyttet den unge generation sammen med mulighederne indenfor bioøkonomien.

- Sørge for klare investeringsstrategier i forhold til at katalysere udviklingen og tiltrække kapital for start-ups og SMV-ere i regionen.

- Overveje at styrke mulighederne for initiativer på lokalt niveau.

- Skabe strategier for og forbindelse mellem lokalproduktion og lokale markeder.

- Bioraffinering kan bidrage til at skabe merværdi fra biomasse.

- Opmuntre til samarbejde mellem industri, uddannelses- og forskningsinstitutioner på alle niveauer i livscyklus for at bidrage til øget relevans af forskning og uddannelse for industrien og dermed booste attraktiviteten i bioøkonomi-relaterede jobs og uddannelser.

- Adressere miljøudfordringer indenfor akvakultur for at sikre bæredygtige aktiviteter og undgå konflikter med lokalbefolkningen.

- Konstruktion af træhuse er i hurtig udvikling i skovrige regioner i Rusland. Det kan bidrage til jobskabning, til bedre utnyttelse af lokale ressourcer og til bedre boliger. Den øgede efterspørgsel efter trækonstruktioner kan overføres til investeringer i mere bæredygtig skovforvaltning og udvikling af skovveje.

- Udvikling af en offentlig politik som skaber aktiviteter og som har målrettet offentlig støtte for lokale fornybare energi ressourcer over fossile ressourcer kan bidrage til at udvikle resiliente energisystemer i udkantkommuner.

- Samarbejde og udviklingspotentiale i området mellem lokal mad, rekreation og naturbaseret turisme kan undersøges yderligere.

Studiet, som er finansieret af Nordisk Ministerråd, 2018-2019, "Kicking off the Bioeconomy in the North", baserer sig på tidligere erfaringer fra et andet studie finansieret af Nordisk Ministerråd i 2018 "Forest and Wastebased Bioeconomy in the Arkhangelsk region". 


\section{Administration and governance in the Russian Federation}

According to the Constitution of the Russian Federation, the Federal Assembly (the Russian parliament) is the representative and legislative body of the country. It consists of two chambers: the Council of the Federation and the State Duma. The Council of the Federation includes two representatives from each subject of the Russian Federation, one each from the legislative and executive bodies of the state authority. The State Duma presently consists of $\mathbf{4 5 0}$ deputies (The Constitution of the Russian Federation, 2001).

In terms of the administrative structure of the Russian Federation, there are 85 regional administrative units, often referred to as federal subjects, with different political and juridical statuses. These comprise 22 republics, 1 autonomous oblast (or region), 46 oblasts and 9 krays (or industrial regions) (oblasts and krays are often simply referred to as regions), along with four autonomous okrugs (or districts) and three cities of federal significance. All these areas are further divided into administrative districts such as rayons (administrative and municipal units), towns, urban settlements and villages (Barentsinfo, 2019; OECD, 2016). Since 2000, these federal subjects of the Russian Federation have been combined into eight federal districts: Central, North-western, Southern, North Caucasian, Volga, Ural, Siberian and Far Eastern. The Russian Constitution did not originally envisage these districts; instead, Federal Government agencies created them for the convenience of governing and operation.

Republics, unlike territories and regions, are ethnicity-based states, each having its own constitution, government and parliament. Oblasts (e.g. Murmansk oblast) have a regional government, led by a governor, and a separate parliament (the Regional Duma) that perform local-level legislative functions, mostly for localising federal laws. Although it may appear as if republics have more political and economic autonomy than oblasts, in practice, there is little difference (Barentsinfo, 2019). The governors are nominated by the political parties and elected by the citizens of Russia (RIA News, 2018b).

The Russian Federation is a centralised state with its administrative, economic and political resources mainly concentrated in Moscow. Among the responsibilities of the federal subjects are the adoption and amendment of the constitution (charter), laws and other legal acts, as well as control over their compliance; the establishment of the administrative-territorial structure; and determination of the system of state bodies in accordance with the fundamentals of the constitutional system of the Russian Federation. These responsibilities also include the general principles of the organisation of legislative (representative) and executive bodies of state power established by federal law; the organisation and development of local governments; and the development of policies and programmes supporting the state, economic, environmental and social development of the subjects of the Federation. Other issues in the joint jurisdiction of the state and federal subjects are those of the ownership, use and disposal of land, mineral, water and other natural resources, administrative, labour, family, housing and forestry legislation and environmental protection.

According to the federal law on the principles of the organisation of local self-government in Russia (adopted in 2013 and amended in 2019), local governments are responsible for issues of local importance such as the organisation of sanitation and the heating, electricity and water supply, strategic planning, approval and implementation of municipal programs in the field of energy efficiency, the organisation of energy checks in multistorey apartment buildings, the development and approval of programs for the municipal, transport and social infrastructure of settlements and urban districts, the provision of public services (library, fire 
brigade, etc.) and organisation of pre-school, basic and secondary education. Local governments approve the local budget and may set, amend and abolish local taxes and fees in accordance with the legislation of the Russian Federation (Federal Law 131-FZ, 2003; RG, 2003).

As a rule, municipalities are struggling to fulfil these duties because of low tax revenues. Consequently, the quality and availability of social services in the municipalities is generally poor. The municipalities may use property taxes to increase revenues, sell land located within the municipal boundaries to private investors and influence the use of land through municipal planning. The municipalities are, however, dependent on the state and local enterprises. This puts enterprises in a special position. Businesses often take upon themselves the provision of municipal services and the burden of taking care of local communities, e.g. through maintaining infrastructure, sponsoring the construction of school buildings and shopping centres, providing heating for flats in the locality and operating the fire brigade and water and sewage. In turn, they often receive compensation in the form of, for example, tax deductions. The socalled 'social responsibility' of enterprises for the surrounding communities, as promoted by President Vladimir Putin, refers to "...a better-managed transition to a market economy with a willingness on the part of companies to participate in developing the Russian economy and social system in co-operation with the government" (Kortelainen and Nystén-Haarala, 2016: 186).

\section{Taxation in the Russian Federation}

The tax code of the Russian Federation establishes three levels of the tax system: federal, federal subjects (regional) and local. Taxes collected at the federal level have the same tax rates. These include personal and corporate income taxes, valueadded tax, excise taxes, water taxes, taxes on the extraction of minerals and state duties (Nalog, 2019).

The Tax Code of the Russian Federation at the federal level also approves regional-level taxes. Regional authorities have the opportunity to change taxation conditions within the limits adopted by the Tax Code. For example, regions can set any tax rate, as long as it is not higher than the amount prescribed in the Tax Code. Regional taxes include transport, gambling businesses and organisational property taxes. Regional authorities can also introduce special tax regimes and make their own changes to these, but again, only in accordance with the provisions of the Tax Code of the Russian Federation (Nalog, 2019). Most of the subjects of the Russian Federation are subsidised, as the budget-forming types of taxes are concentrated in the federal budget, whereas hard-to-collect taxes, such as property taxes, remain in the regions (Bolatayeva et al., 2017). While the law prescribes a minimum level of revenues to remain at the local level, there is presently no law regulating how the state should redistribute revenues to level any economic differences between regions (Kortelainen and Nystén-Haarala, 2016).

The representative bodies of municipal formations establish (and enforce and terminate) the regulatory legal acts of local taxes. The representative bodies of municipalities determine the tax rates, as well as the procedures and deadlines for tax payments, and can establish tax incentives, grounds and procedures for their application. The Tax Code of the Russian Federation determines other elements of taxation for local taxes and taxpayers. Local taxes and fees include:

a land tax (for organisations and individual landowners)

- a personal property tax (for individual property owners)

- a trading fee (paid by firms and entrepreneurs for conducting commercial activities for which a fee is established on the movable or immovable property objects designated for this purpose).

\subsection{Forest management - institutional organisation}

Forests are owned by the Russian Federation. However, federal forest legislation has changed several times over the last 20 years, transferring the responsibilities for forest management between different levels of governance. At the beginning of the 1990s, forest management was decentralised and handed over to local government authorities, while in 1997, the management functions relating to forest land were transferred to a higher governance level (the government authorities of the 83 federal subjects), leaving the legislative and supervisory functions to the Federal Government authority. In 2004, Federal Law No. 122 centralised forest management and transferred forest management functions to federal executive bodies (FAO, 2012). 
Finally, in 2006, the Forest Code was adopted, which is still valid today, and which once again decentralised forest management and transferred state supervisory functions related to forest land to government authorities of the subjects of the Russian Federation (FAO, 2012). At the same time, the Forest Code of 2006 gave the state the power to decide on the revenues from forestry to some extent (Nysten-Haarala and Kotilainen, 2016). This was the calculation of a payment for the provision of forest land for timber harvesting under a lease agreement based on a minimum price defined at the federal level, multiplied by a regional coefficient defined by leaseholders and businesses (Resolution 310, 2007).

Nevertheless, forest management in Russia has been criticised for the unstable position of the federal executive body responsible for forest relations. From 2000 to 2012, the position of the Federal Forestry Agency changed four times between different ministries. Since May 2012, the Federal Forestry Agency has reported to the Ministry of Natural Resources and Ecology (ibid.). Currently, the Federal Forestry Agency is responsible for: 1) forest relations (control and supervision); 2) rendering public services; and 3 ) management of state assets in the area of forest relations. The Federal Forestry Agency does not have representation in the federal districts (ibid.)
At the regional level, forestry departments in the eight federal districts and the 83 federal subjects of the Russian Federation implement federal interests in the area of forest relations. The government authorities in the forestry departments are responsible for: 1) the elaboration and validation of forest plans and legal forestry regulations; and 2) the lease and concession of forest parcels, conclusion of contracts for purchase and sale of wood stock and organisation and carrying out of wood auctions. They are also responsible for: 3 ) the organisation of management, conservation, protection and regeneration of forests; and 4) the implementation of federal forest supervision, etc. In practice, forestry districts (lesnichestva) implement these plenary powers (ibid.). Figure 1 illustrates the institutional organisation of state forest management at the subject level in the Russian Federation.

Private businesses perform forest management in accordance with lease contracts, with the rights to conclude a forest parcel and contracts for the purchase, lease and sale of wood stands acquired by legal and natural persons through wood auctions. Priority investment projects aimed at innovative development of the forest sector fall under an exception and are subject to selection and validation through a tendering procedure (FAO, 2012) (see Section 3.4.1).

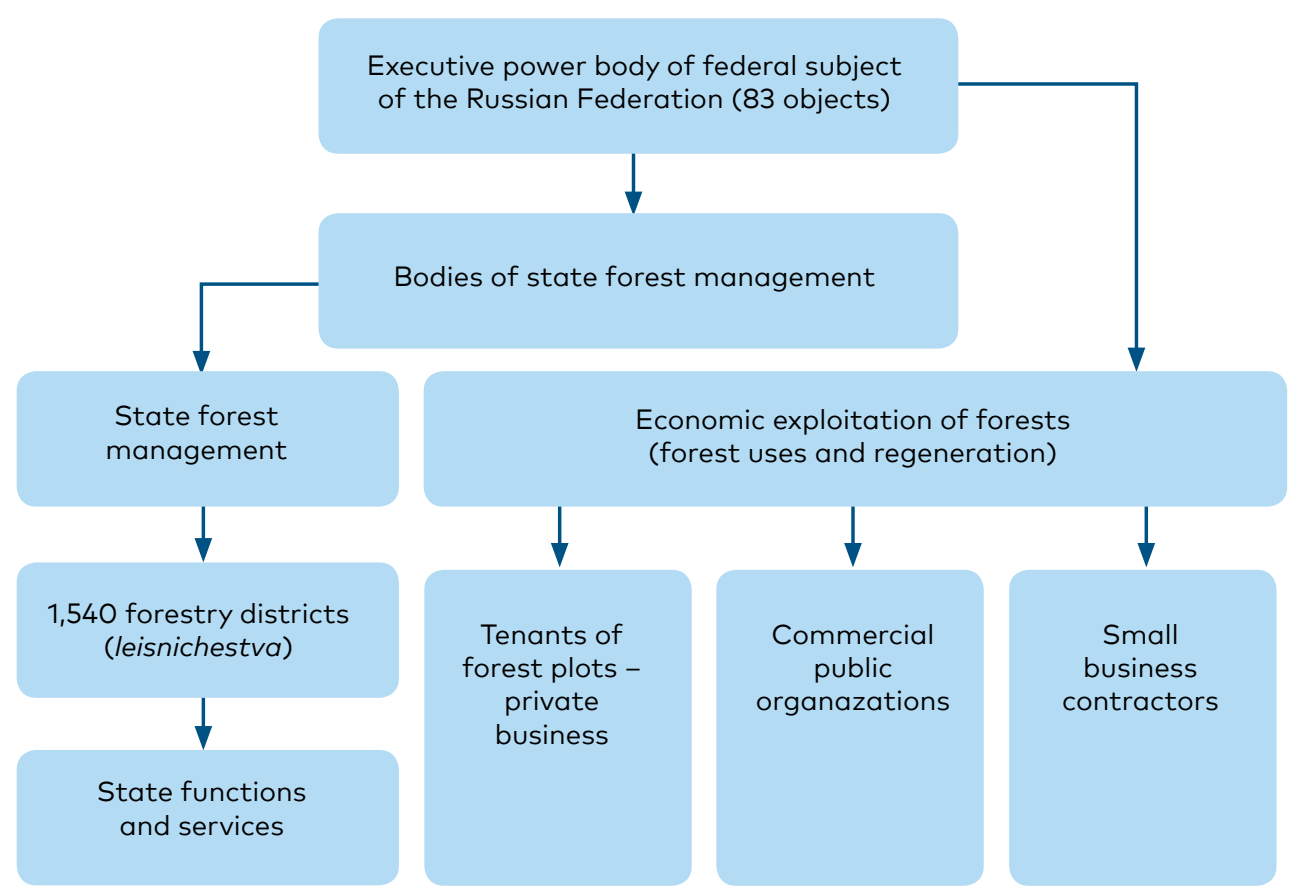

Figure 1. Institutional organisation of forest management in the Russian Federation. Source: FAO, 2012. 


\section{Voluntary certification schemes}

Forestry industries in Russia increasingly recognise the business benefits of voluntary certification schemes, such as the Forest Stewardship Council (FSC), as a means to increase their opportunities and competitive advantage in international markets. Moreover, some forestry enterprises consider voluntary FSC certification more successful in regulating forestry than national forest legislation (Pappila, 2016). In April 2019, there were 29 holders of FSC Chain of Custody ( $\mathrm{CoC})^{1}$ certificates in the Republic of Karelia, 15 combined $\mathrm{FM}^{2} / \mathrm{COC}$ certificate holders and one holder of a CW/FM certificate. $^{3}$ There are currently no PEFC-certified forest owners in the Republic of Karelia.

Besides fostering sustainable forest management practices and making a positive contribution to biodiversity conservation objectives, certification schemes play an important role in catalysing bio and circular economy thinking among enterprises, as the FSC incentivises the reuse, recycling and upcycling of forest waste products. As long as the certification applies to the entire value chain, companies have a greater incentive to utilise waste products, as FSC certification will provide a higher market value; this creates better incentives for companies to invest in secondary production, such as pellet plants.

As elsewhere, the high costs for small forest users and companies to prepare and conduct audits and meet extended social and environmental requirements in some particular cases are among the main limiting factors for companies certifying their operations and products. 


\section{The bioeconomy in the Republic of Karelia}

This section provides an overview of the available biological resources in the Republic of Karelia and describes their current use and potential for further utilisation, as well as current disincentives and hindering factors, which can bring useful insights on what needs to be improved. The focus of this section is on forest and marine biological resources.

\subsection{The Republic of Karelia - key facts and figures}

The Republic of Karelia is one of the federal subjects in Russia and part of the Northwest Federal District. It covers a territory of $180,500 \mathrm{~km}^{2}$, of which, forests account for $85 \%$, and has a $723 \mathrm{~km}$ border with Finland to the west. The main bodies of water in the Republic of Karelia are the White Sea, with $630 \mathrm{~km}$ of shoreline to the northeast, and Lake Onega and Lake Ladoga (shared with neighbouring regions) to the south. Map 2 illustrates the location of the Republic of Karelia and Petrozavodsk, its administrative centre.

In terms of demography, the population of the Republic of Karelia declined by about $16 \%$ from 2000 to 2018 . In 2017, the net migration rate was $-2,463$ persons. In Karelia, urban dwellers constitute about $80 \%$ of the population (2016) (Rosstat, 2018 ). About $27 \%$ of the population in the Republic of Karelia possess higher education, $54 \%$ have a

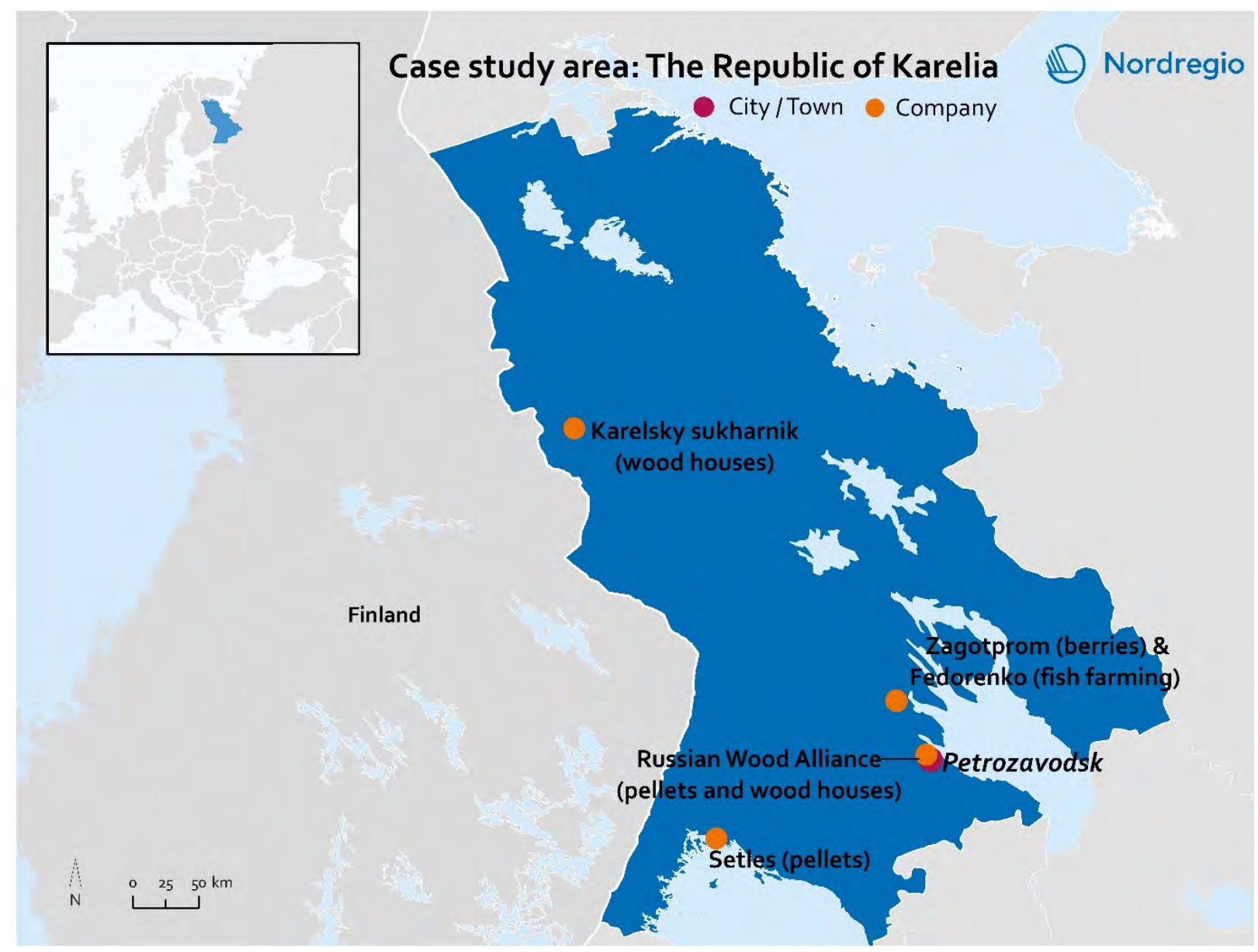

Map 2. The location of the Republic of Karelia, its administrative centre, Petrozavodsk, and several companies involved in bioeconomy activities 


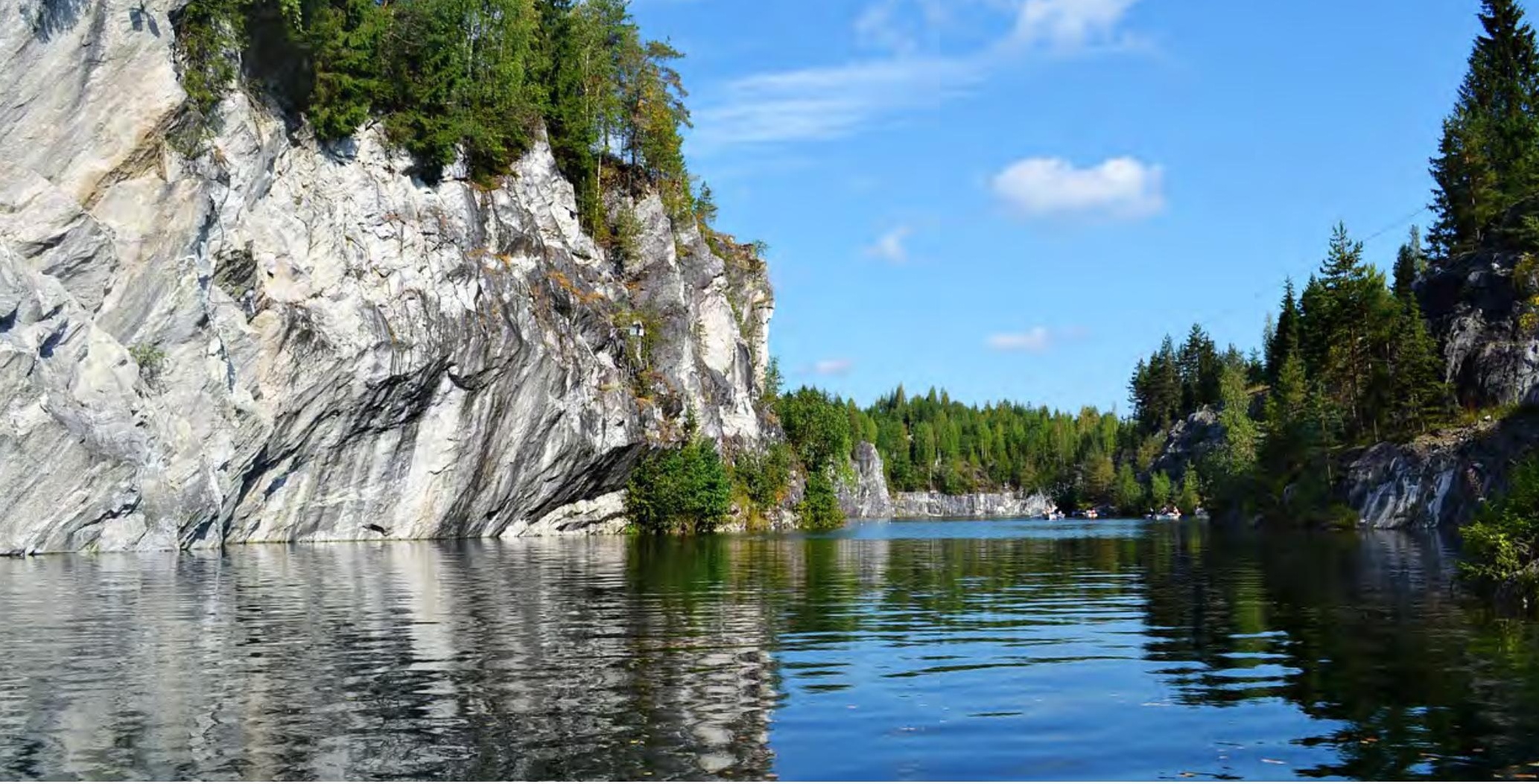

professional/vocational education, approximately $14 \%$ have a secondary education and about $4 \%$ have a basic general education (Rosstat, 2018).

Karelia's economy relies on nature and resource-based industries, with prospects for the development of a bioeconomy determined by the favourable agri-climatic conditions there. Timber, woodworking, pulp and paper industries and ferrous metallurgy are the main industrial sectors (The Republic of Karelia, 2014). According to the
Guide to Investment: Republic of Karelia (PwC, 2014), the competitive advantage of the Republic of Karelia lies within the forest products and mining industries, as well as its advantageous geographical location at the border with the EU, which potentially provides access to both the Russian and EU markets and acts as a logistics hub. Particularly good opportunities for development are also found within the tourism and recreation, food, fisheries and biotechnologies industries ( $P w C, 2014)$.

Table 1. Key facts and figures - Republic of Karelia and the Russian Federation

\begin{tabular}{|c|c|}
\hline Republic of Karelia & Russian Federation \\
\hline $\begin{array}{l}\text { Population: } 622,484 \text { (2018) } \\
\text { Area: } 180,500 \mathrm{~km}^{2} \\
\text { Density: } 3.5 \text { persons } / \mathrm{km} 2 \\
\text { Administrative centre: City of Petrozavodsk } \\
\text { ( } 263,540 \text { ) } \\
\text { Average annual number of employed, thousand } \\
\text { persons: } 290 \text { (2017) } \\
\text { Average per capita money income (monthly), } \\
\text { roubles: } 25,900 \\
\text { Average per capita money expenditures } \\
\text { (monthly), roubles: } 24,675 \\
\text { Accrued average monthly nominal wages of } \\
\text { employees, roubles: } 32,591 \\
\text { Gross regional product (at current prices), bln. } \\
\text { roubles: } 211\end{array}$ & $\begin{array}{l}\text { Population: } 146.8 \text { million persons (2017) } \\
\text { Area: } 17.1 \text { million } \mathrm{km}^{2} \\
\text { Density: } 8.6 \text { persons } / \mathrm{km}^{2} \\
\text { Average annual number of employed), thousand } \\
\text { persons: } 68,389 \text { (2017) } \\
\text { Average per capita money income (monthly), roubles: } \\
30,738 \\
\text { Average per capita money expenditures (monthly), } \\
\text { roubles: } 30,497 \\
\text { Accrued average monthly nominal wages of } \\
\text { employees, roubles: } 36,746 \\
\text { Gross regional product (at current prices), bln. roubles: } \\
64,997\end{array}$ \\
\hline $\begin{array}{l}\text { Regional strengths: Forest products, mining } \\
\text { (iron ore and natural stones), agri-business } \\
\text { (fisheries and fish processing), tourism }\end{array}$ & \\
\hline
\end{tabular}

Source: (Kareliastat, 2019; Rosstat, 2017, 2018) 


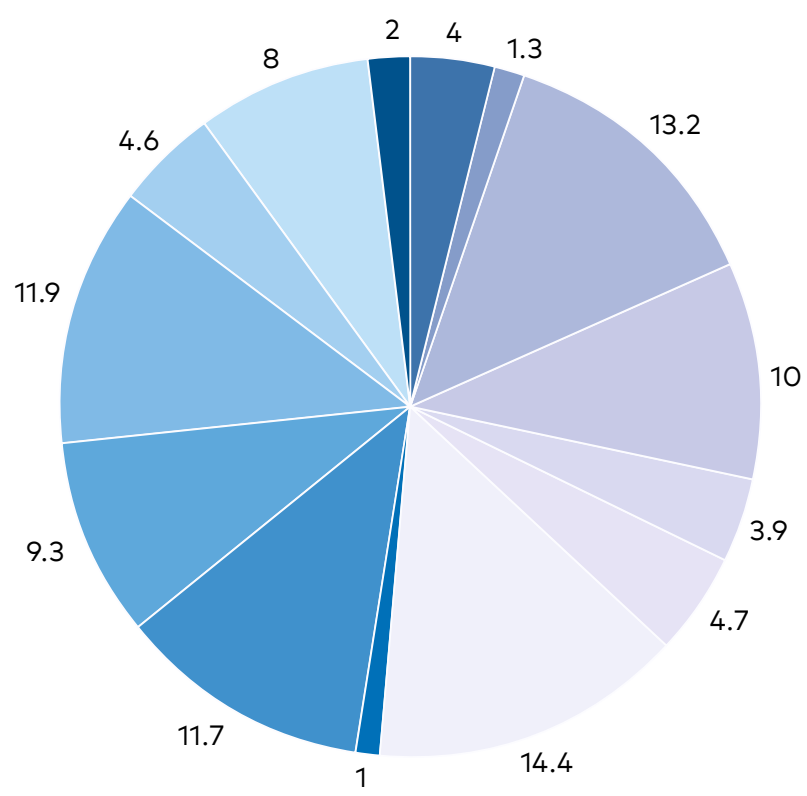

Agriculture, hunting and forestry

Fishing and fish farming

Mining

Manufacturing

Electricity, gas and water production and distribution

Construction

Wholesale and retail trade

Hotels and restaurants

Transport and communications

Real estate, leasing and services

Public administration

Education

Healthcare

Other production

Figure 2. Breakdown of Karelia's economy in 2013 as a share of GRP, \%. Source: PwC 2014.

The Republic of Karelia accounts for about 65$70 \%$ of all trout farmed in Russia, $26 \%$ of iron ore pellet production, $20 \%$ of paper and $12 \%$ of wood pulp and cellulose made of other fibre materials (The Republic of Karelia, 2014). In 2014, exports from the Republic of Karelia accounted for more than $50 \%$ of its total production; over $95 \%$ of commercial cellulose and $84 \%$ of newsprint produced were exported (The Republic of Karelia, 2014).

Figure 2 depicts the value-added of different sectors in the economy of the Republic of Karelia in 2013. As shown, in 2013, the agriculture, hunting and forestry sector accounted for about $4 \%$ of the total gross regional product (GRP), with fishing and aquaculture accounting for another $1.3 \%$. By the end of 2016, the corresponding figures were $4.2 \%$ and $2.1 \%$, respectively (Kareliainvest, 2018). In 2018, the primary industries (agriculture, forestry; fisheries, fish farming) provided jobs to some $3.6 \%$ of the total employed (Kareliastat, 2019).

\subsubsection{Local energy system}

Local energy sources in the Republic of Karelia include peat and wood wastes. Lacking its own hydrocarbon reserves, municipal heating in larger towns is mainly by natural gas, while boiler houses in the smaller settlements use coal, fuel oil, diesel oil and, in some cases, wood wastes ${ }^{4}$.

4 Read more about bioenergy production in Section 3.2.5.
According to an interview with the Ministry of Natural Resources and Environment of the Republic of Karelia, local fuels (mainly firewood) provide about $11.2 \%$ of the heating needs of residential and public buildings in the Republic of Karelia (2017). If the consumption of firewood for furnace heating by the local population is included in the estimations, then the share of this local fuel rises to nearly $24 \%$. The harvesting and utilisation of peat for heating currently takes place in the Pryazhinsky district.

Building new and reconstructing existing boiler houses, as well as upgrading the region's power supply network, are among the more important priorities of the regional authorities. Setting up wood-fired boiler houses was supported in the framework of a Programme for the Long-Term Development of the Electric Power Industry in the Republic of Karelia until 2018 (PwC 2014). However, the modernisation of boiler houses is expensive and moving slowly, as there are no direct subsidies available for refurbishment projects. Moreover, the modernisation and reconstruction of heat networks is required in most cases, which is an additional investment cost (Lesprominform, 2014).

The government of the Republic of Karelia actively promotes further development of the supply infrastructure for natural gas heating in its municipal districts under the Gas Supply and Gasification Master Plan for Karelia developed by OAO Gazprom Promgaz. This plan envisages the supply of natural gas to several municipal districts 
through the construction of pipelines. At this point, about 1,430 individual houses and apartment blocks and more than 10 boiler houses in Petrozavodsk, as well as the Kondopozhsky and Priosnezhsky districts, have been gasified (PwC 2014). However, further development of the supply infrastructure for natural gas heating in the Republic of Karelia is believed to have a negative influence on the popularisation of alternative energy sources, including bioenergy, because of its low cost to users compared with other energy sources (from an interview with regional authorities).

\subsection{Forest-based bioeconomy}

As of 2014, forests in the republic covered some $149,000 \mathrm{~km}^{2}$, of which, the commercial forest fund accounted for 114,000 km² (PwC, 2014; The Ministry of Natural Resources and Ecology of the Republic of Karelia, 2019). Approximately $95,000 \mathrm{~km}^{2}$ of forest plots in the republic were leased out for timber-harvesting purposes in 2014 (PwC, 2014). Coniferous species account for almost $90 \%$ of the forest resources (60\% pine, 30\% spruce, 10\% birch and aspen).

According to the actors interviewed, the current state of the forest resources in the Republic of Karelia is characterised by a deterioration in the age structure of stands, with an increasing share of young and middle-aged stands, and a decreasing share of stands suitable for logging. There is also change and deterioration in the composition of species and a deterioration in the commodity structures. There are six forest nurseries in the Republic of Karelia with a total area of about 113 ha (interview with a research actor).

\subsubsection{Forest management}

The Ministry of Natural Resources and Ecology of the Republic of Karelia is the authority responsible for forest management and the analysis and development of the timber industry complex, forest use and reforestation and forest protection, ensuring compliance with the forest legislation and environmental supervision (interview with research actors).

The demand for raw materials from forests has increased by a third over the past 5 years in the Republic of Karelia. Ensuring a sufficient supply of raw materials to the forestry industries formed the basis for the development of the Strategy for the Development of the Forest Industry Complex of the Republic of Karelia Until 2030, which was approved by the head of the Republic of Karelia in April 2019. This strategy promotes the improvement of forest legislation, intensification of forest use, development of the forest road network, renewal of fixed assets of enterprises, increasing wages of the forestry industries employees, increased domestic processing and utilisation of round timber, as well as the increased utilisation of wood-based residues and low-value raw material (The Republic of Karelia, 2019b).

Increasing the volume of thinning activities and adopting an intensive forest management and reproduction model are among the measures outlined in the strategy that aim to increase the supply of raw materials. In Scandinavia, harvesting volumes per hectare of forest are currently some 5-6 times higher than that in the Republic of Karelia, which is partly achieved through more intensive thinning (The Republic of Karelia, 2019b).

Today, the restoration of about $63 \%$ of all logging in the Republic of Karelia is by means of natural reforestation, mainly by applying the socalled natural overgrowth method. Applying the intensive forest management and reproduction model proposed in the strategy would allow an increase in the utilisation of middle-aged stands for economic activities and increase the frequency of harvesting activities, resulting in an increased volume of timber removal from the forest of up to 1-2 million m3 per year. Among the challenges for the transition to a new forest management model is that it will require applying a different logging technology and purchasing new technical equipment for which no extra funding has been envisaged (The Republic of Karelia, 2019b).

\subsubsection{Forestry industry}

The forestry industry is among the leading sectors in Karelia's economy. According to interviews with the research actors and a representative from the Ministry of Natural Resources and Ecology of the Republic of Karelia, the timber industry complex currently accounts for about $30 \%$ of the total output of the industrial sector and provides employment to some 12,600 people (2018). In 2017, approximately 6.4 million $\mathrm{m}^{3}$ of raw timber, 854,000 $\mathrm{m} 3$ of sawn timber, $369,000 \mathrm{~m}^{3}$ of oriented strand boards (OSB) and chipboard and 931,000 tons of paper were produced in the Republic of Karelia (data obtained from the research actors). Figure 3 (next page) provides the corresponding figures from previous years (PWC 2014). 


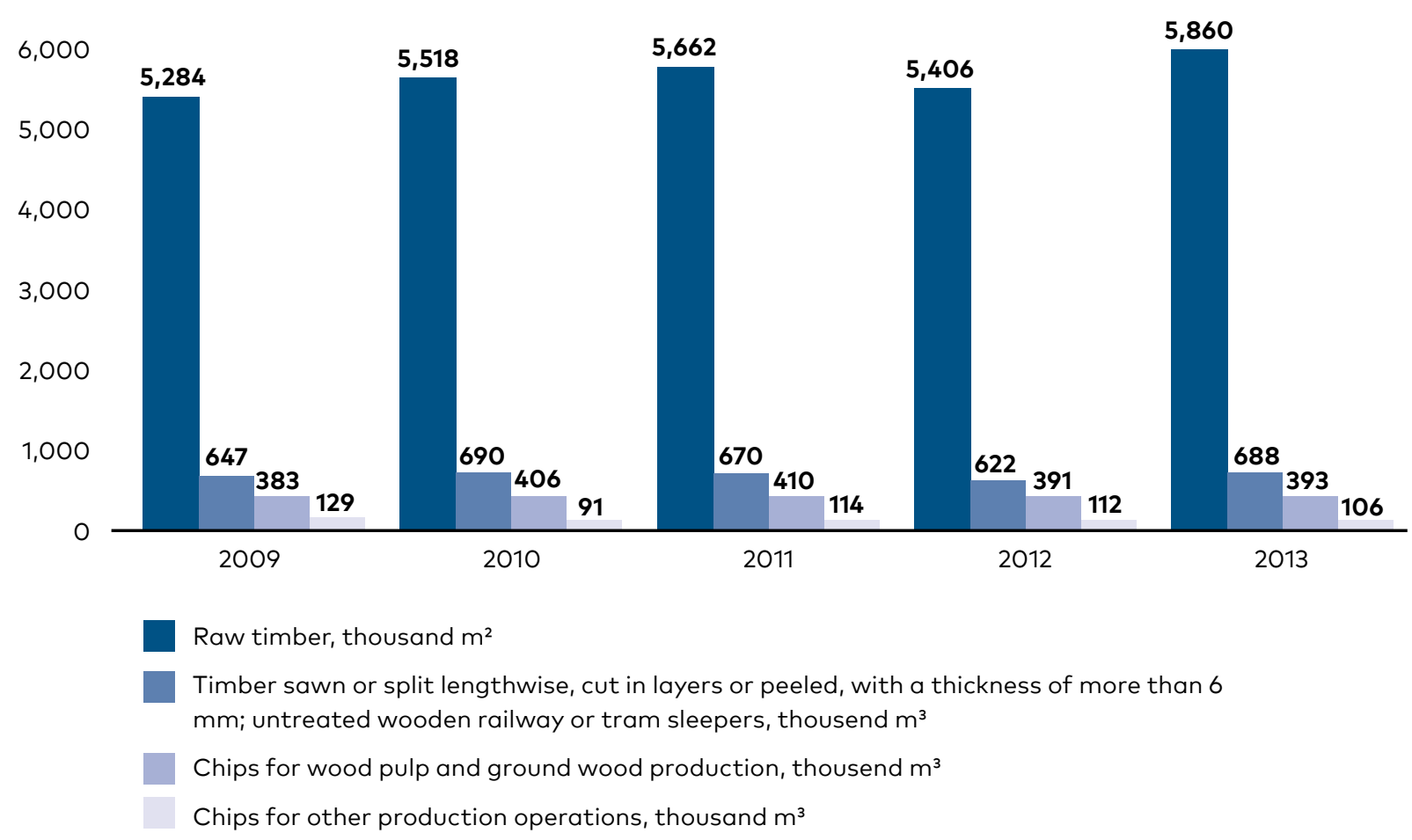

Figure 3. Production of forest industry products in the Republic of Karelia. Source: PwC 2014.

Currently, the forestry industry in the Republic of Karelia comprises 408 organisations, of which, eight are large timber mills (interview with the research actors). Box 1 lists the largest pulp and paper industries in the republic.

Presently, it is estimated that there are about 550,000 tons of timber industry waste produced in the Republic of Karelia annually, of which, bark waste is almost entirely utilised by the enterprises for heating, whereas the utilisation of sawdust that has accumulated over time remains a challenge (The Republic of Karelia, 2018). There are some $670,000-1,000,000 \mathrm{~m}^{3}$ of logging residues produced in Karelia annually. As it stands, there is no removal of these logging residues from the forest and they are not included in production activity because of their poor economic potential (interview with regional authorities).

There are currently two enterprises in the Republic of Karelia, namely the 'Russian Wood Alliance' and 'Setles', producing pellets and fuel briquettes, of which, about $80-90 \%$ of production is for export. In addition, the 'Solomensky Lesozavod Timber Mill' is planning to commence a fuel briquette production line in 2019 (interview with the Ministry of Natural Resources and Environment of the Republic of Karelia). Pellets are currently in low demand on the domes- tic market because of the relatively high prices. In recent years, there has been a strong focus on supporting both the increased processing of forest resources in the republic and the technological modernisation of the forest industry complex (interviews with regional authorities and research representatives). Support for this has been

\section{BOX 1. Key forestry industries (pulp and paper producers) in the Republic of Karelia}

Segezha Pulp and Paper Mill. This mill produces wrapping paper, sack paper and paper bags. The products are sold in Russia, the Commonwealth of Independent States (CIS) and abroad.

Kondopoga. This pulp and paper mill is one of the largest newsprint producers in Russia and Europe. It provides employment for nearly 3,500 people.

Pitkäranta Pulp Mill. This mill produces market pulp and wood-chemical products and exports to the CIS, the EU, Southeast Asia, Africa and South America (PwC 2014). 


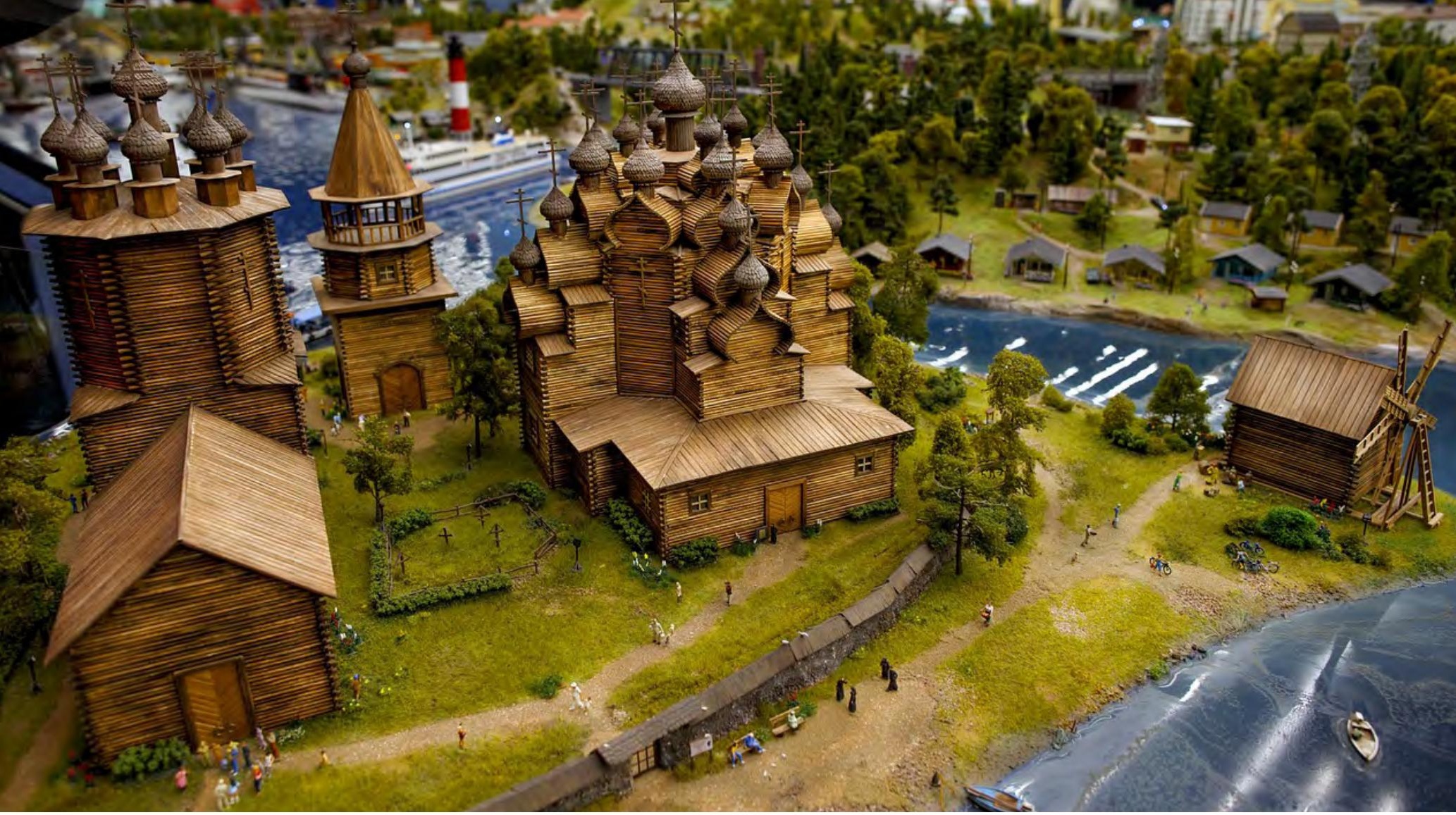

Wood in construction is an old tradition in the Northwest Russia. Source: Pixabay.

through the framework of the so-called 'priority investment projects' ${ }^{5}$, large-scale activities funded from the budget of the Republic of Karelia that aim to have a considerable impact on the socioeconomic development of the region.

Currently, six priority investment projects in the field of forestry industries are being implemented in Karelia. These projects aim at modernising the infrastructure that will improve energy efficiency, enable an increase in production volume and the processing of wood wastes and create new jobs at the companies concerned, namely the 'Kalevala Woodworking Plant', 'FinTek', 'Kostomuksha Construction Company', 'Setles', the 'Russian Wood Alliance' and 'Segezha Pulp and Paper Mill'.

Among the examples of already realised priority investment projects is the first stage of the modernisation of the 'Segezha Pulp and Paper Mill'. A new papermaking machine was purchased in 2017, and a new biomass-fired boiler plant for steam production used for the technological processes of the plant was put into operation in 2018.

5 The basis for inclusion of a project in the list of priority investment projects is the decision of the Ministry of Industry and Trade of Russia and the Ministry of Natural Resources and Environment of the Republic of Karelia (Kareliainvest, 2019b; What Wood, 2019). The investment project should also comply with a set of criteria (see Box 3 in Section 3.4.2).
New equipment allows the mill to use wood wastes and sewage sludge as fuel, and has the capacity to produce some 120 tons of steam per hour. The modernisation of the mill is expected to continue in 2019 as a second-stage investment project (Kareliainvest, 2019a).

The construction of a new large-scale wood processing facility at the 'Kalevala Woodworking Plant' was initiated in the Republic of Karelia in 2013. This plant produces the OSB used in low-rise housing construction. Increasing the production capacity of the plant is considered a second stage of the investment project in the future.

\subsubsection{Construction of wooden houses}

The construction of wooden houses is gaining popularity in the Republic of Karelia and in Russia as a whole, primarily triggered by its low cost and the high demand for new housing, given the poor quality of the existing housing stock. The main challenge for housing construction in Karelia today is to secure the flawless process of emergency housing resettlement, which started in 2014. In 2018, in the framework of the resettlement programme, more than 8,300 residents of Karelia received new apartments. The new program, approved on 28 March 2019, predicts the resettlement of more than 9,000 people until 2025 (The Republic of Ka- 
relia, 2019a). One of the local companies is planning to build wooden framed houses to be used for the resettlement program at a reasonable cost, which is possible because of the large volume of required construction and the use of the locally produced materials (The Republic, 2019).

The 'Russian Wood Alliance' is among the largest companies in Karelia producing houses from rounded logs. Another producer in the market for wooden houses is 'Karelsky Sukharnik', which has been manufacturing wooden houses from polar pine, including wooden windows, doors and planed boards, since 2010. This company specialises in using dry (so-called 'dead') trees for construction, which is an accepted practice in Russia and Finland, but not in other countries such as Sweden. The company focuses on supplying wooden houses to the domestic market. Elsewhere, the Karelian Business Centre promotes development and investment in the production of wood-polymer composites, mechano-chemically modified wood and powder fillers for the 3D printing of houses in the Republic of Karelia (interview with the Karelian Business Centre).

\subsubsection{The use of other biological resources from forests}

Wild berries and mushrooms are among the biological resources from forests that have the potential to be utilised in an emerging bioeconomy in the Republic of Karelia. Natural production is about 62,000 tons of wild berries per year, of which, only about $15 \%$ is currently harvested, along with some 70,000 tons of mushrooms, of which, less than $10 \%$ is used in commercial activities (interview with a regional authority). 'Zagotprom' is a manufacturing company involved in the gathering and cleaning of wild berries (cloudberries, blueberries, lingonberries and cranberries) and mushrooms in the Republic of Karelia. The products are supplied to manufacturers of berry extracts, liqueurs, jams and preserves, both domestically and internationally (e.g. China, Japan, Finland, Sweden). Among the more well-known buyers are Valio and Polarica.

In 2014, 'Zagotprom' received a grant from the European Bank for Reconstruction and Development to build a plant for the advanced processing of berries into extracts. In 2018, the regional government of the Republic of Karelia allocated a land plot of 3.5 ha for the construction of the plant in the Territory of Advanced Socio-economic Development (TAD) in Kondopoga without public ten- der. As an industry located in a TAD, the company will gain a number of additional economic benefits, including, for example, company tax rates approximately four times lower for the next 10 years (read more about TADs in Section 3.4.1). The plant is expected to be ready in 2021 (interview with the owner of the company).

\subsubsection{Bioenergy production from forest-based residues}

In 2014, there were nine boiler houses with a capacity up to 3.5 megawatts ( $M W$ ) each fired with woodchips and firewood in the Prionezhsky and Pryazha districts (Lesprominform, 2014). Among the barriers for bioenergy production in the Republic of Karelia today is the lack of a steady supply of woodchips and their relatively high price for domestic consumers. This can be explained by the fact that large forestry companies such as the 'Segezha Group' and 'Karellesprom' use woodbased residues for their own heating purposes or sell these abroad given the higher price offers (Lesprominform, 2014; interview with Karelian Centre for Energy Efficiency).

\subsection{Marine-based bioeconomy}

\subsubsection{Fisheries and aquaculture}

The fisheries sector in the Republic of Karelia includes sea and oceanic fishing, freshwater fishing and freshwater aquaculture. In 2014, Karelia's fisheries sector included 241 businesses, of which, 46 were involved in sea and oceanic fishing. Sea and oceanic fishing take place in the fishing zone of Russia in the Barents Sea, in a 200-nautical mile zone of international waters, as well as in open areas of the north-eastern Atlantic Ocean. The total catch of fish from the sea and ocean in the Republic of Karelia amounts to some 30,000 tons per year.

Although the farming of rainbow trout commenced in the Republic of Karelia in the 1980s (Sterligova et al., 2008), it has only become a profitable economic activity in recent years (AIF Karelia, 2017b). Fish farming takes place mainly in deep freshwater reservoirs, with fish farming activities in the White Sea currently confined to pilot projects.

Nonetheless, aquaculture is one of the fastest developing economic sectors in the Republic of the Karelia given the favourable natural and climatic conditions and closeness to markets, as well as the economic sanctions that have triggered the 
implementation of a policy for import substitution (AIF Karelia, 2017b). Production has almost doubled since 2010, attaining 27,000 tons by 2018 (see Table 2). Today, the Republic of Karelia produces three-quarters of all trout farmed in Russia (Russia Beyond, 2016).

There are long-term plans in the Republic of Karelia to increase commercial fish farming further, backed by significant support at the regional and federal levels. Biologists and fisheries experts (e.g. the Trout Farmer Society of Karelia) have set the upper limit to the growth of fish farming activities in fresh waters of the Republic of Karelia to 3035,000 tons per year (AIF Karelia, 2017b; Dzjubuk and Ryzhkov, 2014; Karelinform, 2018b). Above these production volumes, fish farming is expected to have severe consequences on the environment.

Fish farming in the White Sea offers additional opportunities for the expansion of activities. In 2017, a fish farming company called 'Siedleckie' tested commercial fish farming in the White Sea to estimate the potential benefits and risks (interview with a fishing enterprise).

Table 2. Aquaculture production in the Republic of Karelia.

\begin{tabular}{|c|c|}
\hline Year & Production (tons) \\
\hline 2000 & 1,160 \\
\hline 2005 & 5,000 \\
\hline 2010 & 14,500 \\
\hline 2015 & 17,500 \\
\hline 2017 & 23,000 \\
\hline 2018 & 27,000 \\
\hline
\end{tabular}

Adopted from Sterligova and IImast (2018) and (Stolica Onego, 2019).

In 2017, there were 58 fish farms in the Republic of Karelia, mostly local companies. 'Kala ja marjapoyat', 'Segezerskoye', 'Kala-Ranta' and 'Fedorenko' were among the largest producers, with some 15 fish processing enterprises with a total production capacity of nearly 12,000 tons of fish products per year. The largest producer was ' $\mathrm{Fe}$ dorenko', with a production capacity of 5,000 tons of fish products per year.

Several large-scale investment projects are currently being implemented in the Republic of Karelia to stimulate the production of higher value- added products and increase the utilisation of fish wastes and residues:

A fish processing plant in Kondopoga district by 'Fish Trading Network' with maximum production capacity reaching 50 tons products per day. The enterprise will produce cod and haddock fillets and salted and dried cod. Fish flour will be produced from fish residues. According to the initiators of the project, the plant will become one of the largest fish processing enterprises in Northwest Russia (interview with a fisheries expert).

- The construction of a plant for the deep processing of fish and fish residues by 'The Parabola Group' in the city of Petrozavodsk with a capacity of up to 3,000 tons per year, including 2,000 tons of ocean fish species and up to 1,000 tons of rainbow trout. Investment to total 300 million roubles (4.1 million euros).

The construction of a fish and algae processing plant in Belomorsk Rayon on the coast of the White Sea is planned in the future, and another smaller fish processing plant has recently been built in the Medvezhiegorsk area (Nevski News, 2018).

\subsubsection{Utilisation of fish wastes}

Approximately 2,000 tons of fish wastes are produced in the Republic of Karelia each year (Shcherbak and Tishkov, 2014). While the utilization of fish wastes to solve the problem of waste disposal and increase the value-added of fish products is not yet a common practice, it has recently been given priority on the regional government agenda. Among the more common ways of currently disposing of fish wastes are landfills (Shcherbak and Tishkov, 2014) and combustion (AIF Karelia, 2017b).

There are currently two large companies with the necessary facilities for fish waste processing, namely 'Fedorenko' and 'Kala ja marjapoya', with the construction of two new facilities in the pipeline (see above). 'Kala ja marjapoya' has a processing line producing veterinary fish oil, while 'Fedorenko's new modern plant processes fish wastes into fish flour and different types of fat, including medical fat (fish oil for the production of vitamins and various additives), veterinary fat for animal feed and technical fat, which commenced in 2018 (AIF Karelia, 2017a; interview with fisheries experts). The plant has a capacity to utilise up to a ton of fish waste per hour. The regional government has provided investment support of 9 mil- 
lion roubles (123,000 euros) to 'Fedorenko' for the purchase of the equipment, which corresponds to about $30 \%$ of the equipment costs (Karelinform, 2018a). The entrepreneur has stated that he will purchase fish wastes from other companies in the Republic of Karelia (AIF Karelia, 2017a; interview with fisheries experts).

At the same time, from an economic viewpoint, the transport of fish wastes has been identified as one of the main challenges for increased fish waste utilisation in Karelia in an interview with the research actors. The high costs of transportation are associated with a scattered location of aquaculture companies and additional requirements for transportation, as fish wastes are classified as dangerous goods. The processing of fish wastes appears to be economically feasible only if it takes place at a facility in close proximity to the aquaculture companies. As it stands, the quantities of fish wastes produced by the companies were found to be too low to make fish waste processing profitable for single firms.

A feasibility study on the potential of the utilisation of fish wastes in the Republic of Karelia was conducted by Shcherbak and Tishkov (2014) under the framework of the Karelia ENPI CBC AQUAREL project (see Box 2). The authors found that the production of fish flour and fish feed from fish wastes has the highest potential. The production of biodiesel was found to be not economically feasible because of the high investment costs in the technology and the rather low volumes of fish wastes generated in the Republic of Karelia. Further, while the production of biogas has potential, it is hindered by the low price of natural gas and

BOX 2. The AQUAREL project aimed to analyse the potential of using fish wastes from aquaculture activities in the Republic of Karelia for biofuel production or other purposes. analysis The project included research (e.g. and estimation of available fish wastes) and productivity and investment calculations, as well as testing of the equipment and piloting. One of the companies started fish waste processing in their own premises based on the project pilot phase results and findings (Keep Database, 2014a) the lack of both a modern waste management system and state support, as well as the relatively low environmental awareness of the population and companies (Shcherbak and Tishkov, 2014).

\subsubsection{Future perspectives for fish forming}

Increasing fish farming production capacity and the competitiveness of the industry are high on the agenda in the Republic of Karelia. At the same time, the dependency on foreign supplies and technical limitations have been identified as the main challenges for the growth of the industry. Among the key challenges are the high cost of imported fish feed, the lack of a fish breeding centre, the absence of qualified and skilled workers and poor infrastructure development (interview with fisheries experts).

To address the aforementioned challenges, the regional government identified the production of domestic feed for commercial fish farming, the development of its own fish-breeding centre and the increased processing of fish residues as prioritised development areas.

The production line of domestic fish feed will gradually replace imports of feed from Finland, Denmark, France and Italy. The launch of a new plant, 'Karelian Fish Factory Feed', in 2017 is part of the solution. The company's current production capacity is some 4,000 tons of fish feed per year, with the aim of increasing this to 17,000 tons by 2020 , corresponding to approximately $40 \%$ of the fish feed needs in the Republic of Karelia (interview with fishing experts). The construction of the plant is supported in the framework of the Action Plan for the development of the aquaculture cluster in the Republic of Karelia.

The construction of a fish-breeding centre will commence in 2019. This plant received a 900 million rouble ( 12.3 million euro) investment allocated by the Federal Agency for Fisheries under the framework of the federal program 'Development of the Fishery Complex'. This centre is expected to meet $50 \%$ of the demand for breeding material in the Republic of Karelia (Stolica Onego, 2019).

According to the fisheries expert interviewed, there is a great interest in developing closed systems for aquaculture production (e.g. recirculating aquaculture systems) in the Republic of Karelia. This could enable the cultivation of valuable thermophilic fish species. However, in realising future plans for the expansion of aquaculture in the Republic of Karelia, it is important to ensure the en- 
vironmental sustainability of production. Conflicts with the local population regarding the environmental aspects of production have already taken place. Earlier this year, about 200 residents of the Kondopoga district opposed the expansion of fish farming activities on Lake Sandal because of the perceived negative impact on the quality of water and the deterioration of the lake ecosystem. This is particularly because Lake Sandal is connected to Lake Nigozer, which serves as a drinking water reservoir for the town of Kondopoga (AIF Karelia, 2019). According to Vladimir Labinov, the Minister of Agriculture and Fisheries of the Republic of Karelia, conflicts with the local population emerge because of inadequate control and monitoring over the ecological status of the water bodies used for fish farming. One of the reasons for this is a lack of mobile labs in the republic, which makes it impossible to examine the quality of water at trout farms directly (AIF Karelia, 2019).

\subsection{Policy framework and state support for the bioeconomy \\ 3.4.1 Federal-level support}

Given the heavy reliance on imports of forest products and marine resources (FAO, 2012), and following the introduction of economic sanctions in 2014, the Federal Government has put a strong emphasis on strengthening local bioeconomy sectors. This support has a dual objective: a decrease in imports and an increase in the export of high value-added products.

On the one hand, a so-called import substitution policy was introduced acting as an important driver for the development of a local bioeconomy, triggering significant investment in the development of innovation potential along the whole value chain of aquaculture and forest-based industries and adding value locally. On the other hand, increased state support has been provided to export-oriented businesses producing high valve-added products willing to enter international markets. Financial assistance has been provided for marketing and information support to small and medium enterprises (SMEs), business coaching and training programs and the organisation of business missions and partnerships (interview with a regional authority representative). In the Republic of Karelia, for instance, those efforts led to a $12.6 \%$ increase in the export of Karelian production in the first quarter of 2019 compared with 2018; in addition, exports of timber and pulp and paper products increased by $11.5 \%$ (Russian Export, 2019).

Customs policy pursued by the state also aims at stimulating the development of local processing industries and producing higher value-added products. This policy implies that protective tariffs are applied to low-processed products (e.g. round wood), resulting in their higher taxation compared with higher value-added products (interview with a regional authority representative). In 2019, export duties for unprocessed timber increased from $25 \%$ to $40 \%$ and were expected to increase further, by up to $80 \%$ by 2021 (Customsonline, 2019).

The Russian government aims to stimulate the socio-economic development of certain areas throughout the entire country by creating so-called TADs under the framework of a Federal programme that entered into force in 2014. Generally speaking, TADs provide favourable conditions for investors, including significant tax and customs privileges.

The Republic of Karelia has two TADs: Kondopoga (established in 2017) and Nadvoitsy (established in 2016). These territories have a preferential investment climate, including a reduced tax rate on profits of $5 \%$ instead of the standard tax rate of $20 \%$, no land or property tax and lower employment taxes aimed at promoting external business investments and improving socio-economic development. In the Kondopoga and Nadvoitsy TADs, a special legal regime for business activities was established to support business investment in wood processing and the manufacture of wood and cork products, excepting furniture, straw products and paper and cardboard products, among other areas (Kareliainvest, 2016b, 2016c).

\section{Support to the forestry industry}

A key political document supporting the development of the forestry industry in Russia is the Strategy for Forest Industry Development in the Russian Federation until 2030 adopted in 2018. This strategy foresees the multifaceted utilization of forest resources and focuses on value-added wood processing industries. Among the highest priority areas outlined in the strategy are the construction of wooden houses and wood waste recycling into biofuels (The Russian Government, 2018c). However, there is currently no action plan.

Priority investment projects are important tools that have been used to stimulate the development of certain industries and sectors in the 
Russian Federation since 2007. Priority investment projects are subject to selection and validation through a tendering procedure. Until recently, priority investment projects in forest-based industries were considered to be those relating to the setting up and modernisation of wood-processing infrastructure (including bioenergy production) and forest infrastructure (forest roads, timber depots, etc.) to no less than 300 million roubles ( 4 million euros). Since the beginning of 2018 , the priority investment projects in forest-based industries are considered those related to modernising forest infrastructure (including the processing of wood wastes and bioenergy production) with a minimum capital investment of at least 500 million roubles ( 6.8 million euros). They also include the setting up of wood-processing and forest infrastructures (including the processing of wood wastes and bioenergy production) with a minimum capital investment of at least 750 million roubles (10 million euros) (The Russian Government, 2018b).

The construction of wooden houses

Supporting the construction of wooden houses is high on the agenda of the government, not least due to the generally poor quality of available housing. There are a number of political initiatives aimed at increasing the share of wood in construction and renovation, e.g. through the realisation of a national project 'Available and Comfortable Housing for Russian Citizens' and the Strategy for Developing the Building Materials Industry until 2020 that aims to increase the output of prefabricated wooden houses to 2.9 million $\mathrm{m}^{3}$. The government also supports the development of the wooden housing market through facilitation of the lease of allotments of public land for low-rise wooden housing construction and the realisation of priority investment projects stimulating refabricated wooden housing construction by 2020 with an annual production output of 300,000-320,000 houses (FAO, 2012). At the same time, the political initiatives aim at minimising imports as a means of reducing the penetration of foreign producers into the market (FAO, 2012).

\section{Support to fisheries and aquaculture}

Russia is in the midst of restructuring its seafood sector. Significant investment support is available in infrastructure and other aspects of the fisheries industries. The Strategy for the Development of the Russian Federation Fisheries Complex for the Pe- riod until 2020 aims at transforming the fisheries industry from being centred on raw material exports to developing innovative higher value-added products and better value chains (Jóhannesson and Sigfusson, 2018).

To support the implementation of this strategy, the government introduced an investment quota mechanism to enable priority to be given to those enterprises willing to invest in the processing of fish resources either on the coast or on fishing vessels. This measure aims at stimulating the modernisation of a relatively old fishing vessel fleet and upgrading fish processing technology in exchange for an increase in fishing quotas for 15 years (Jóhannesson and Sigfusson, 2018).

In 2017, the Ministry of Agriculture approved the Strategy for the Development of Marine Terminals until 2030. This strategy is most relevant for large harbour hubs such as Murmansk, where the problems addressed in the strategy are particularly acute. The strategy calls for attracting public and private investment in refurbishing and expanding fishing terminals, along with eliminating the administrative barriers and lengthy processes associated with the landing of fish at domestic fish terminals (including increasing the efficiency of veterinary and customs procedures) and increasing the quality of services provided to fishing vessels in ports. These measures aim to attract more fishing companies to use Russia's own fishing terminals to land their catch and repair their vessels, thereby boosting the national economy and delivering more fish to Russian consumers (Stupachenko, 2018a, 2018b; The Russian Government, 2018a). However, while this strategy may contribute to the increased landing of catches at Russian terminals, it may not be effective in simulating the supply of fish to the domestic market, as the export of seafood remains more economically profitable for companies.

\subsubsection{Regional-level support}

According to an interview with the Corporation of Development of the Republic of Karelia, Karelia is one of the leading regions of Russia when it comes to the wide range and variety of state support measures available for businesses and investors. In most cases, priority is given to large-scale investment projects with investments exceeding 200 million roubles $(2,760,000$ euros).

The program of the Republic of Karelia Development of Agro-industrial Complex and Hunting 
Economy of the Republic of Karelia until 2025 is the main mechanism for the development of the agro-industrial and fisheries complex. This program envisages subsidies for the reimbursement of part of the costs of interest loans received in Russian credit institutions provided to fish farmers and the direct reimbursement of costs for the construction of fish feed and fish processing plants and the creation of a fish-breeding centre. The subsidies concern the purchase of feed, veterinary equipment and young animals, as well as investment loans for up to 8 years for the construction, reconstruction and modernisation of farms for the implementation of commercial fish farming. The subsidies from the regional budget for the purchasing of fish farming equipment in the form of reimbursements of up to $30 \%$ of the costs of equipment, including that for processing biological waste from fish farming, are considered important support measures and were used by the 'Fedorenko' enterprise (page 20) (interview with a fisheries expert).

Moreover, the Ministry of Economic Development of the Republic of Karelia and the Corporation of Development of the Republic of Karelia drafted a regional law on the state support of biotechnological and food industries adopted in 2017. The provides state support measures such as subsidies for the partial compensation of interest rates on loans, subsidies for the partial compensation of equipment acquisition costs, preferential tax rates on property tax and preferential tax rates on income tax credited to the regional budget. Under these measures, the income tax can fall from $20 \%$ to $13.5 \%$.

Under the framework of this law, 'The Concept for Creating a Biotechnological Cluster in the Republic of Karelia' developed in 2017 has four main priority areas:

processing of wild plants and medicinal raw materials (e.g. production of wild berry extracts, artificial cultivation of wild mushrooms);

a increased processing of aquatic bioresource (e.g. products from algae, functional food products, processing of wastes from aquaculture);

- increased processing and utilisation of forest and wood industries' wastes (e.g. processing of logging residues, tops and branches and birch round wood for energy and biopolymers production);
The Corporation of Development of the Republic of Karelia is a public organisation supporting regional development through facilitating the development and implementation of investment projects. It provides support in e.g. developing a business plan and finding investors.

recovery and reproduction of bioresource potential (e.g. developing a breeding and genetic centre for fish farming) (interview with the Corporation of Development of the Republic of Karelia).

Among the priority investment projects in the field of processing of wild plants that are currently in the implementation stage are the production of freeze-dried products based on berries, the production of dry berry extracts with a high content of enthocyanins (implemented by 'Zagotprom') and the production of a natural cosmetics line (interview with the Corporation of Development of the Republic of Karelia).

In addition to the targeted support measures presented above, the regional government may

BOX 3. An investment project is recognised as a priority investment project of the Republic of Karelia if it complies with at least three of the following criteria:

- investments are made in the form of capital investments;

- new jobs are created;

- resource-saving technologies are introduced;

- the investment project has high social significance;

- the investment project is implemented on the territory of a single-industry municipality or town (11 in the Republic of Karelia)

and several other conditions, among others: - the investment project is in line with the long-term economic development priorities of the Republic of Karelia;

- a significant volume of investments; - the creation of new jobs, corresponding to a minimum of $3 \%$ of the total population permanently residing in the locality where the project will be realised (Kareliainvest, 2013). 
support investment projects (not necessarily in the field of bioeconomy) during different stages of development and implementation through:

granting a tax exemption on regional taxes: reduced tax rates on profits;

- reducing tax rates on corporate profits allocated to the Republic of Karelia's budget;

- granting subsidies from the Republic of Karelia's budgetary funds for partial reimbursement of interest expenses on loans obtained for financing investment projects;

- granting preferential terms for the use of land and other types of real estate;

- granting subsidies from the Republic of Karelia's budgetary funds for partial reimbursement of expenses related to cadastral activities, etc. (Kareliainvest, 2013; Kareliainvest, 2016b; PwC, 2014).

The Industry Development Fund of the Republic of Karelia. This fund provides support to the modernisation and development of new Russian industries and supports import substitution activities. The fund offers preferential conditions for co-financing projects aimed at developing new high-tech products and technical re-equipment and creating competitive industries based on the best available technologies. The fund also offers preferential conditions for the co-financing of projects aimed at developing high-tech products, technological modernisation and the development of competitive industries using the best available technologies. The fund also provides loans at the rate of $5 \%$ per annum for a period of up to 5 years for the amount of 5 to 100 million roubles $(69,000$ to 1,380,000 euros) for the purpose of stimulating direct investment (Ministry of Natural Resources and Ecology of the Republic of Karelia, 2016).

\subsection{Educational and research institutions enabling the transition to a bioeconomy}

The Republic of Karelia is the main hub for forestry-related education in the Northwest Federal District of Russia. It has 23 establishments of secondary vocational education, two universities and four branches of federal higher education establishments (Kareliainvest, 2016a). Petrozavodsk State University (PetrSU) is one of the largest universities in the Northwest Federal District of Russia. PetrSU provides a wide range of bachelor's programs with relevance to the forest-based bio- economy. These include the Forestry Programme (Sustainable Multipurpose Forest Utilization), Technology and Equipment of Logging and Woodworking (Technologies and Management of Forest Industry Complex) and Ecology and Management of Natural Resources. It also offers a study programme on Water Biological Resources and Aqvaculture (Fish Breeding). At the master's level, among the relevant programmes are Forestry (Sustainable Forestry and Landscape Design), Ecology and the Environmental Management (PetrSU, 2019).

Vocational education and training in the field of forestry has been provided at the ShuiskoVidanskaya Forestry School since 1951. The school provides education, for instance, in tree felling and as a harvester and forwarder operator. The school collaborates with major equipment manufacturers such as John Deere, Ponsse and Komatsu (Valmet) (Forestry School, 2019). Forestry-relevant education has also been provided at the Petrozavodsk Forestry College since 1924. Today, this college offers education in landscape gardening and construction, forestry and forest park economy, woodworking and logging technology and logging and the operating of skidding machines (Petrozavodsk Forestry College, 2019).

The Karelian Research Centre of the Russian Academy of Sciences (KarRC RAS) represents the research and academic environment. The Forest Research Department is one of seven departments at KarRC RAS, with fundamental scientific research accounting for more than $80 \%$ of all research conducted (Kareliainvest, 2016a). KarRC RAS is engaged in various research and development projects in the field of biotechnology, including the production of biologically active substances from birch (biturin, suberin). The Forest Research Department of KarRC RAS has several priority areas, including research on the acceleration of timber growth, re-cultivation of dumping sites, the use of coniferous raw materials in biomedicine, biotechnology of clonal micro-propagation and the utilisation of by-products from the pulp and paper industry (interview with the research representatives).

In addition, the innovation system in the Republic of Karelia is supported by the regional innovation complex and the IT park of PetrSU, the Ukko innovation centre, the Karelian Centre for Technology Transfer and Innovation at KarRC RAS and a business incubator (Kareliainvest, 2016a). 


\section{The bioeconomy in Murmansk oblast}

\subsection{Murmansk oblast - key facts and figures}

Murmansk oblast is a federal subject of the Northwest Federal District in Russia (see Map 3). It covers an area of $144,900 \mathrm{~km}^{2}$ and is located on the Kola Peninsula, an area rich in minerals and other natural resources. Owing to its Arctic location, the region is characterised by a harsh climate; however, the Gulf Stream keeps the harbour in Murmansk ice-free year round. Murmansk's harbour is the largest in the Northwest Federal District and provides the backbone of the city's economy.

The region borders Finnmark County in Norway to the northwest, the Lapland Region in Fin- land to the west, the Republic of Karelia to the south and the Barents Sea and the White Sea to the north and southeast, respectively.

From 1990 to 2018, the population in the oblast declined by $36.5 \%$. Murmansk is among the most urbanised regions in Russia, with some $92 \%$ of the population living in urban areas (Rosstat, 2018). Almost $32 \%$ of the population in Murmansk oblast possess higher education; $48 \%$ have professional/ vocational education, $17 \%$ have secondary education and about $3 \%$ have a basic general education (Rosstat, 2018). For further socio-economic facts, see Table 3.

Murmansk is an industrialised region with the

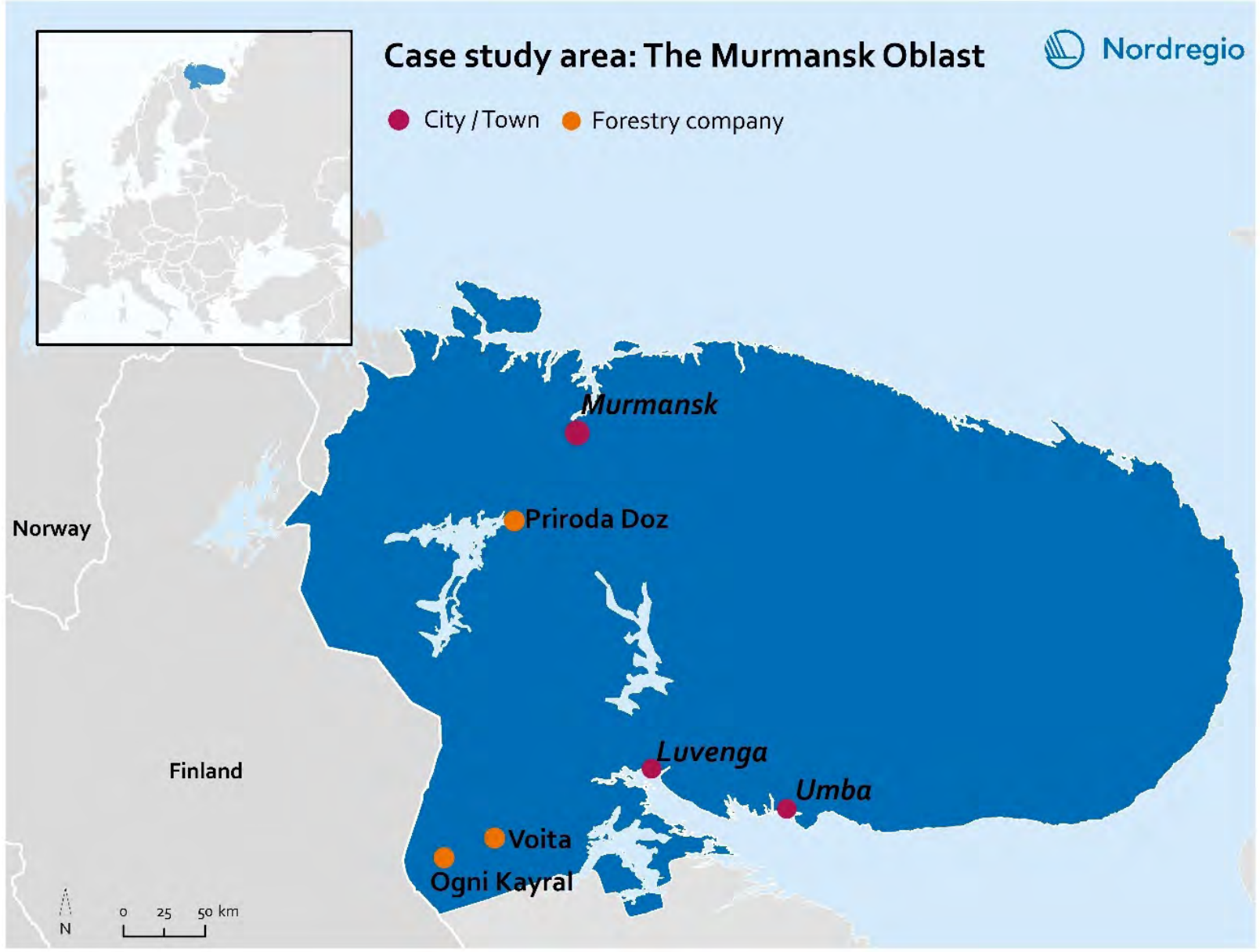

Map 3. Map of Murmansk oblast and some companies involved in the bioeconomy 
Table 3. Key facts and figures - Murmansk oblast and the Russian Federation.

Murmansk oblast
Population: 757,000 (2018)
Area: $144,900 \mathrm{~km} 2$
Density: 5.5 persons $/ \mathrm{km}^{2}$
Administrative centre: Murmansk $(295,374$ in 2018)
Regional strengths: mining of apatite and minerals,
harbour activities, logistics

Average annual number of employed, thousand persons: 398 (2017)

Average per capita money income (monthly), roubles: 36,149

Average per capita money expenditures (monthly), roubles: 34,180

Accrued average monthly nominal wages of employees, roubles: 48,715

Gross regional product (at current basic prices), bln. roubles: 390

Regional strengths: Forest products, mining (iron ore and natural stones), agri-business (fisheries and fish processing), tourism

Source: (Rosstat, 2017, 2018)

mining of apatite, nickel and other minerals and the production of fertilizers being the dominant industries. In 2016, the economic sectors providing key employment in the region (employed persons in brackets) were wholesale and retail trade $(62,000)$, machine production $(42,000)$ and transport and communication (40,000). Primary sectors (agriculture, forestry, fishery, fish farming) provided additional 12,000 jobs (Rosstat, 2018), with the fisheries sector accounting for about $10.2 \%$ of the GRP of the Murmansk region in 2016 (Vassiljev, 2018).

\subsubsection{Local energy system}

The region is self-sustaining in electricity production. In fact, it has a surplus of energy given the low regional demand. The Kola Nuclear Power Plant, inaugurated in 1973, currently works at about $60 \%$ of its capacity, as the demand for energy has decreased significantly since the collapse of the Soviet Union and the downsizing and restructuring of industries.

At the same time, the price of heating is high in the region because of the limited supply of locally available energy fuels and the high costs associated with the import of fuels for heating, as well as a worn out infrastructure, resulting in poor energy efficiency. Reducing the price for heating is therefore among the main drivers for the modernisation of the regional heat supply system, which

\section{Russian Federation}

Population: 146.8 million persons (2017)

Area: 17.1 million $\mathrm{km}^{2}$

Density: 8.6 persons $/ \mathrm{km}^{2}$

Average annual number of employed, thousand persons: 68,389 (2017)

Average per capita money income (monthly), roubles: 30,738

Average per capita money expenditures (monthly) roubles: 30,497

Accrued average monthly nominal wages of employees, roubles: 36,746

Gross regional product (at current basic prices), bln. roubles: 64,997 is a priority investment project in the Murmansk region. At present, there are some 120 old boiler houses in the region requiring modernisation (interview with a regional authority).

The investment plan for the modernisation of the regional heat supply system supports the substitution of fuel sources to those less environmentally harmful than fuel oil (even coal is considered) and the deployment of more technologically advanced equipment that would allow an increase in energy efficiency. The plan also supports the increased utilisation of local fuel sources such as peat-and wood-based residues and aims to reduce heating tariffs for the local population through achieving higher energy efficiency. In several settlements, the construction of new coal-fired boiler houses and the modernisation of existing boilers are ongoing (BezFormata, 2019b; Hibiny, 2018a).

There is no natural gas supply to the region. The former governor of the oblast claimed that gasification is among the most important preconditions for the economic development of the region, as it would significantly reduce energy costs, which are currently double the Russian average (15.3\% versus $7 \%$ ) (RIA News, 2018a). The possibility of liquefied natural gas is being discussed with Gasprom. However, despite these talks, the local actors interviewed were sceptical about the prospects of gasification of the region in the coming decades. 
Nonetheless, the gasification of the region would not solve the problems associated with heating of remote settlements. Here, the future is still behind coal and fuel oil, although the consumption of bioenergy may increase. Among the reasons for the low utilisation of wood wastes for heating in the region is the low productive capacity of its forests and poorly developed transport infrastructure. For more information on the current status of bioenergy production, see Section 4.2.1

Few alternative energy projects are piloted in the region. In 2017, Enel Russia announced a project to build the region's first industrial wind farm, with a capacity of $200 \mathrm{MWt}$, in Teriberka. The construction of the wind farm will begin in 2019 and is expected to be ready in 2021 (Bellona, 2018).

\subsection{Forest-based bioeconomy}

Forests cover about $35 \%$ of the land area in Murmansk oblast, or some 9,455,387 ha (Ministry of Natural Resources and Ecology of Murmansk oblast, 2019). About $35 \%$ of these forested areas are designated for commercial purposes, with protected areas constituting about $8 \%$ of the oblast's territory.

Due to the harsh climatic and weather conditions inherent to the northern territories of Russia, the productivity and the economic exploitation potential of forests is low. At present, the forestry sector brings about 40-50 million roubles (553690,000 euros) to the regional budget annually, which is rather insignificant (interview with a regional authority).

The annual allowable cutting rate is currently utilised to up to $16.3 \%$ (Ministry of Natural Resources and Ecology of Murmansk oblast, 2019). The forest-based bioeconomy is represented by traditional and rather small forestry industries. There are four forest leaseholders in the region, 'Ogni Kayral', 'Voita', 'Priroda Doz' and 'Arctic Wood', all of which are located in the southern part of the region, three in proximity to the border with Finland, which gives better access to foreign markets. While these companies have satisfactory access to logging sites and infrastructure, most of the eastern part of the region is inaccessible to land transport. In general, the poor state of forest road infrastructure is considered a challenge for the development of the sector, according to several interviewees.

Biotechnology is an emerging development area, primarily driven by research establishments in the region with a specific focus on biomedicine.

\subsubsection{Bioenergy production}

There are several boilers in the oblast that use peat- and wood-based residues as a fuel source, such as the multi-fuel boiler in the Umba urban settlement fired with peat and coal, and a woodchip-fired boiler house in Luvenga village (2012). Moreover, several forestry enterprises use woodchips to heat their industrial premises (e.g. Ogni Kayral' and 'Priroda Doz').

In 1999, 'Priroda Doz' pushed for the construction of a boiler house in a nearby village that could be fired with woodchips produced at the plant. The boiler was inaugurated and worked for a few years (until about 2007). However, the success of the initiative was undermined by technological hurdles (power adjustment issues of the purchased boiler) and disagreement with the local authorities concerning the payment for woodchips. Since 2007, the company has been selling its woodchips to Finland instead.

Woodchips and biofuels should be the future when it comes to heating in small and remote settlements in Murmansk oblast. Unfortunately, the future belongs to the fuel oil (Alexander Dvorjankin, Priroda DOZ forest enterprise).

Another bioenergy project that was initiated in the region 5 years ago also had limited success. A converted boiler experienced technological failure and ceased to be operational after half a year.

The locational decision for the establishment of a woodchip-fired boiler house in Luvenga village was criticised in an interview with a forestry company. The closest forestry companies are located over 100 km away (see Map 3), making it economically difficult to transport wood wastes over long distances.

Among the reoccurring issues in the implemented bioenergy initiatives that have undermined their success rate has been the purchasing of 'semi-appropriate' equipment as an incentive to save costs. This appears to have been a failed strategy in the long term, including the unsatisfactory payment, or even lack thereof, to the companies for the supply of wood-based residues (interviews with a forestry industry representative).

Peat is the cheapest locally available fuel in the region and is projected to be available for extraction for about 60 years (BezFormata, 2019b). The environmental and climate change concerns associated with peat extraction have not yet been widely discussed in the region. 


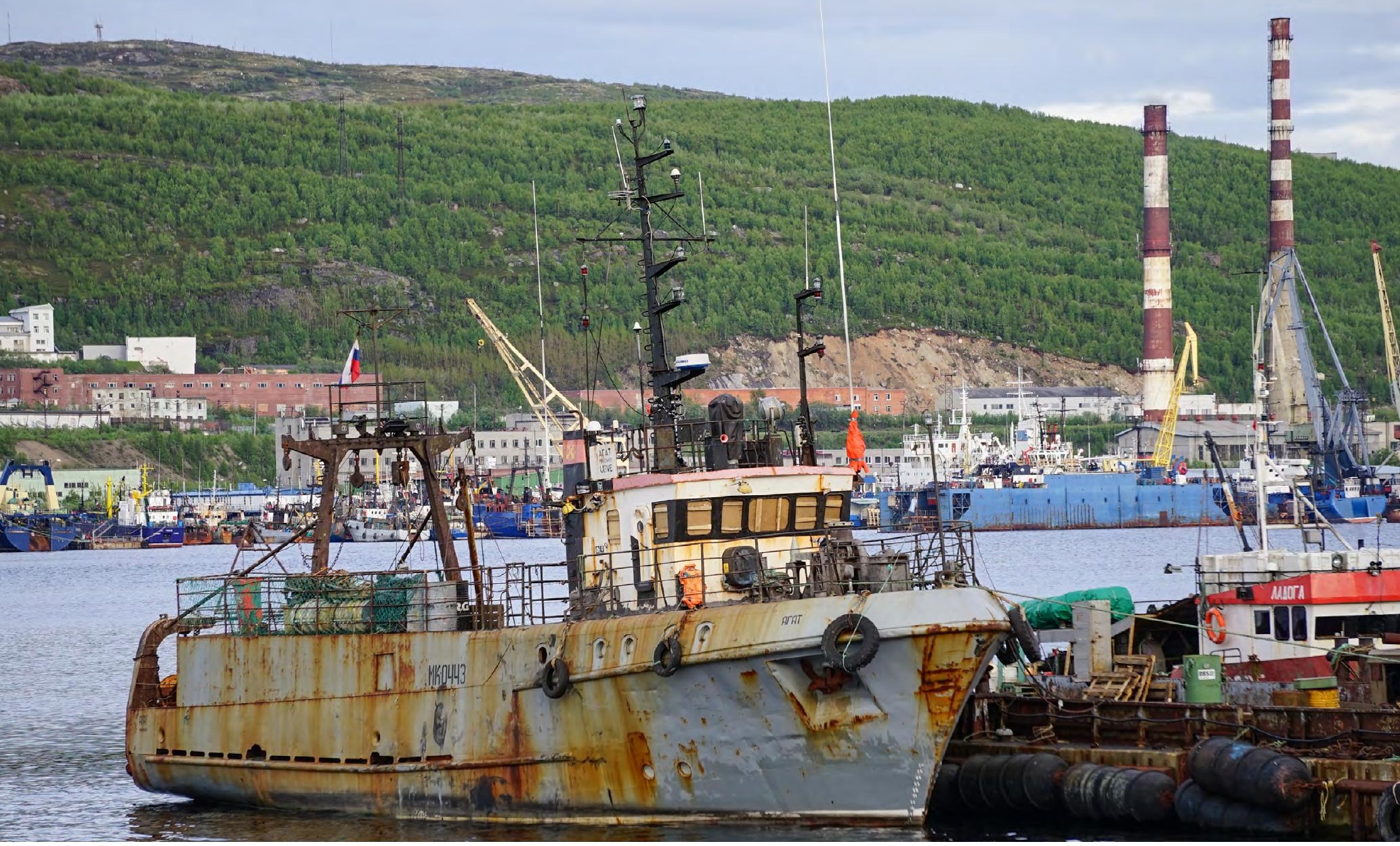

and appearance, wooden housing construction will continue to be demanded in many rural areas in the region, including Kola, Teriberka, the White Sea coastal communities and others, where wood has been the main building material for centuries. Moreover, the rapidly developed local tourist sector is using wooden guest and country houses for the accommodation of tourists and related activities.

To sum up, there is a potential market in the Murmansk region for both wooden building materials and technologies, found primarily in private individual housing, building in historical settlements and in the tourism and leisure sector. Local building companies are in crucial need of modern knowledge, new experience and innovations for wood-based energy-efficient building in cold climate conditions.

\subsection{Marine-based bioeconomy}

\subsubsection{Coastal and oceanic fisheries}

The fisheries sector was particularly strongly developed in the Murmansk region during Soviet times, but underwent a major reduction and downsizing in the 1990s. Market transformations in the fishing industry in the 1990s and early 2000s resulted in legal, regulatory, structural and organisational changes, as well as an overall decline in catch volumes. The catch volumes of fish by Murmansk enterprises amounted to some 600,000 tons in 2000 , which was $48.6 \%$ lower than that even in 1990. In 2016, the total catch increased slightly, amounting to 643,000 tons. In 2016, there was a total of 108 companies involved in fishing activities (mainly oceanic) in the region, of which, 23 were large fishery companies (Vassiljev, 2018). The total catch of seafood (including king crabs) amounted to 702,000 tons in 2017. Additionally, 226 tons of fish were harvested in the region's freshwater bodies (Northwest Marine Business, 2018).

Today, a very small share of the fish catch is landed in Murmansk. One reason is the small quota distribution to coastal fishery companies ( $6 \%$ amounting to just 30,000 tons of catch) that supply fish to domestic consumers. As in many other countries, the quota system for fish catch gives a preference to those with larger economic resources to compete for the quotas (see Box 4), thereby putting pressure on small coastal fisheries and communities. Consequently, the coastal fishery companies work at only about half their 
capacity and struggle to survive, while the coastal fish processing enterprises have limited access to fresh raw material at affordable prices. Thus, despite the Barents Sea being a richly endowed fishery, there are hardly any fish available for the local population, at least not at affordable prices. Since 2014, fish consumption in Russia has decreased by half, and prices have tripled (RG, 2018; Vassiljev, 2018). According to data from 2016, more than $70 \%$ of the catch goes unprocessed for export (Vassiljev, 2018), primarily to Japan, China, the Republic of Korea and the EU (The Russian Government, 2018a).

Another reason why the volumes of fish handled in Murmansk continue to drop drastically is the poor state of infrastructure at the Murmansk Fish Port and railway, as well as rigid customs regulations and bureaucratic hurdles at the port that make it easier for fishermen to land fish in neighbouring Norway and Holland (Staalesen, 2017). In 2016, more than 100,000 tons of fish were landed in each of these two countries (Staalesen, 2017). In addition, due to the ageing port infrastructure, it is much more attractive for the fishing companies to receive maintenance abroad, as the speed and quality of services are higher than those in Russia (Stupachenko, 2018a).

\subsubsection{Development of fish processing}

\section{BOX 4. Distribution of fishing quotas among companies in Murmansk}

'Norebo Holding' has the largest share of quotas in the Russian Barents Sea, accounting for about $50 \%$ of the cod and haddock catch, or some 180,000 tons in 2018. Other large fishing enterprises holding quotas in the Murmansk region are 'Murmanseld-2' (15,000 tons), 'Murmanrybflot-2' (10,000 tons) and 'Murmanseafood' (12,000 tons) (interview with a fishing expert). 'Norebo Holding' stands out among other regional companies in Murmansk as a highly modern and successful enterprise that receives stable deliveries from its own fleet of trawlers. Established in 2016, the facility lies across the bay from the Murmansk Fish Port. It includes the latest processing technology developed in Iceland and is able to produce 40,000 tons of fish products daily (Staalesen, 2017).

\section{enterprises}

Further support to the development of the coastal fish processing enterprises is considered very important for the region. Fish processing enterprises have a great potential to increase the utilization of fish wastes and diversify production and advance innovation, and thereby increase the value-added of fish products. Nevertheless, the lack of investment in the development of coastal fish processing remains a problem for the region, as the mainshare of investments is provided to the modernisation of the fishing fleet and vessels (Vassiljev, 2018).

Plans for the construction of six modern fish processing factories have recently been announced in Murmansk (The Russian Government, 2018a). These plants would require an additional $50-60,000$ tons of fish raw material per year to ensure the economic viability of their operations. According to the current quota distribution, the existing fish processing plants already suffer from a limited supply of raw biological resources, with more than 10 fish processing companies in the region being on the verge of bankruptcy (Kostrov, 2018). The regional companies and fisheries experts question the need for building new factories when the existing ones are being closed because of a shortage of raw materials (RG, 2018; The Russian Government, 2018a). The importance of supporting the existing regional fish processing companies has been emphasised by the interviewees.

\subsubsection{Utilisation of fish wastes}

The research actors interviewed emphasised the importance of integrating fish waste processing technologies at the new factories or the construction of a self-standing plant that would enable the processing of fish wastes into fish flour and protein hydrolyzate and other high-value components and ingredients. Several pilot initiatives for the processing of fish wastes into valuable products have been undertaken, but the overall contribution of these activities is rather marginal. It is still common practice to dispose of fish wastes overboard. With rare exceptions, frozen heads are brought on shore. Onshore fish processing enterprises sell frozen fish wastes either to feed fur animals in other regions in Russia or for the production of pet food in the Moscow region (Nestle, Mars) (interview with a fishery expert).

However, the processing of fish wastes into protein hydrolyzate is being realised by the Biomarin company. This company produces about 200- 
$300 \mathrm{~kg}$ of protein hydrolysate per month, which is used in the pharmaceutical and food industries (interview with research representatives). According to the Russian news agency TASS, an agreement was reached between the regional government, Biomarin and the organising committee of the Russian competition 'Regions - Sustainable Development' on providing investment support to this pilot initiative that would enable the full-scale commercial production of up to 2-3 tons of protein hydrolysate per month (Fish Portal, 2017).

\subsubsection{Sustainable fisheries}

According to the regional actors interviewed, the proximity to Norway has a positive impact on the sustainability of fishery management. Both countries have well-developed co-operation in the field of sustainable fisheries, and the World Wildlife Fund (WWF) in Murmansk is working on the promotion of sustainable fisheries and the conservation of seabed ecosystems in the Barents Sea. Together with the large fisheries associations of the Northern Basin, the WWF has promoted the modernisation of bottom trawling, which ordinarily has a severe impact on the seabed and its marine ecosystem. Field tests of the experimental bottom trawl model were carried out in the Barents Sea (WWF Russia, 2017). Moreover, the organisation developed an Integrated Environmental Management Plan for the Russian part of the Barents Sea in 2015 (WWF Russia, 2015).

\subsubsection{Aquaculture}

According to 2017 data, the Murmansk region ranks second in the Northwest Federal District in terms of the volume of farmed fish, lagging behind the Republic of Karelia. In 2017, there were 20 companies in the region involved in commercial fish farming that produced about 13,500 tons of fish (Helion Ltd., 2018).

The take-off of aquaculture development in Murmansk has not been a complete success story. In 2015, two major aquaculture producers in the region experienced severe challenges. 'Russian Salmon' declared itself bankrupt while 'Russian Aquaculture' experienced massive fish deaths at its facilities after disease broke out in overfilled cage nets. More than 2,000 tons of dead salmon were dumped and left rotting at several sites in the region, some later incinerated (Staalesen, 2015).

'Russian Aquaculture' has since revived its commercial activities and is currently taking a leading position on the aquaculture market in the Murmansk region. Today, the company deploys Norwegian fish farming technology and occupies almost all areas suitable for fish farming along the coast of the Barents Sea, except for the cages in Liinakhamari belonging to 'Russian Salmon'. In 2018, the company announced plans to increase its salmon production in the Barents Sea to 30,000 tons by 2025 , compared with its current production of 6,000 tons (Gerden, 2018).

According to an interview with a fish farming expert, among the key problems that aquaculture companies are facing in the Murmansk region today are a lack of experience, the remoteness of cages and poor infrastructure, as well as the high costs associated with the import of planting material and fish feed.

To sum up the situation with fisheries in the Murmansk region, the State Programme of the Murmansk Region Development of the Fisheries Complex 2014-2020 identified the following challenges for the development of the fisheries industries in the Murmansk region:

the old fishing fleet and worn-out and outdated fish processing techniques;

- a narrow range of fish products produced;

- a lack of innovative and high value-added fish products in the share of production;

a a lack of institutional support for the innovative development of the fisheries complex;

the complex and lengthy procedures for the provision of maintenance services in the port.

\subsection{State support and the policy framework for the bioeconomy}

For federal-level support, see Section 3.4.1.

\section{Regional-level support}

When it comes to the forestry sector, there are no priority investment projects or mechanisms for supporting sustainable forestry management in the region, nor is there support available for the increased utilisation of renewable fuels, which makes it difficult for wood-based residues to compete with coal and other cheap energy sources in the local energy supply. The investment plan for the modernisation of the regional heat supply system is currently the main support scheme that favours the utilisation of local renewable fuels, such as woodchips.

Considerably more support is provided to 
stimulating the development of the aquaculture and fisheries sectors. In 2013, the regional government approved the programme on Development of the Fisheries Complex in the Murmansk Region for 2015-2020. Among the main aims of the programme was to support the development of innovative and higher value-added products from fish and thereby reduce the export of raw materials. The programme aims to stimulate the development of aquaculture and the modernisation of production facilities, and to support the deployment of innovative technologies (Government of Murmansk oblast, 2013).

The regional government of Murmansk oblast provides support to enterprises involved in aquaculture and coastal processing. It provides subsidies from the regional budget for reimbursement of part of the costs for purchasing equipment, raw materials and auxiliary materials (Helion Ltd, 2018), and of the costs for paying interest on loans received from Russian credit institutions for the development of commercial aquaculture (Votinova and Votinov, 2017).

In 2017, state support for fisheries enterprises was granted to three coastal fish processing enterprises in the Murmansk region for reimbursing part of the cost of paying interest on loan agreements for the purchase of raw and auxiliary materials at the expense of the regional budget, amounting to 6.57 million roubles $(90,000$ euros). In the field of aquaculture, two fish breeding organisations in the region received a total amount of 110 million roubles ( 1.5 million euros) in 2017 to reimburse part of the cost of paying interest on loans received from the Russian credit institutions for the development of aquaculture (Ministry of Fisheries and Agriculture of Murmansk region, 2018).

The federal and regional governments are also actively promoting public-private partnerships (PPP) as a tool to attract investment into municipal infrastructure, including the modernisation of boiler houses. The municipal authorities can provide favourable conditions for investors (e.g. by providing municipal premises or a location without an auction at a favourable price). The Corporation of Development of Murmansk oblast is a public agency that works at, among other things, attracting investment to the region. Promoting PPP and developing competencies for building PPPs are some of the recent focus areas of the organisation.

A TAD was created in the single-industry city of
Kirovsk to support socio-economic development. The law on TADs provides state support through substantial tax and customs privileges aimed at promoting external business investments (Glushkov, 2017). Since its launch in 2017, TAD Kirovsk has attracted six investors (B-Port News, 2019).

\subsection{Educational and research institutions enabling the transition to a bioeconomy}

There are no forestry-related educational programmes in the Murmansk region. The nearest educational establishment that provides education and training in the field of forestry and forestry industries is in the Republic of Karelia (Petrozavodsk State University) and the Arkhangelsk Region (Northern [Arctic] Federal University named after M.V. Lomonosov).

Murmansk State Technical University (MSTU) is supervised by the Federal Fisheries Agency, and the integration of university research and the fishing industry is one of its key tasks. Among the relevant programs in bioeconomy at the bachelor's level are aquatic bioresources and aquaculture (aquatic bioresources and aquaculture in the Arctic region; fisheries industry management; biology [general biology, bioecology, biochemistry, microbiology] and biotechnology [food biotechnology, general biotechnology]). Similar programmes are offered at the master's level, as well as industrial fisheries (fisheries management) (MSTU, 2019).

Murmansk Marine Fisheries College has been part of the university complex of MSTU since 2013. It is one of five educational centres established by the Federal Fisheries Agency and one of the leading educational institutions of the Northwest region. Relevant programs in intermediate vocational education in bioeconomy include ichthyology, fish farming and industrial fishing (Murmansk Marine Fisheries College, 2019).

Murmansk Arctic State University is the oldest and largest university in the region. It has several bioeconomy-relevant programmes at the bachelor's and master's levels, including BAs in ecology and environmental management (environmental management in the Arctic) and biology (hydrobiology and ichthyology), and an MA in biology (ecology) (Murmansk Arctic State University, 2019). Biotechnology is also an important theme at Murmansk Arctic State University. The university coordinates a strategic project aimed at developing innovative biotechnologies and bioengineering so- 
lutions for the Arctic areas, with a specific focus on improving the health conditions of Arctic residents.

Kola Scientific Centre of the Russian Academy of Sciences is based in the Murmansk oblast. It has a long history of co-operation and support to the mining industry, and mining-related research and development remains its main specialisation. The centre also has a research program focused on the processing of fish resources for the produc- tion of collagen and other ingredients used in the health care sector. The potential utilisation of algae biomass for energy production and other uses has also been analysed by researchers at the Kola Science Centre. Since 2018, the centre has been increasingly focused on R\&D in the field of biomedicine and biotechnology, particularly human adaptation to life in the Arctic and reducing the effects of Arctic conditions on human health. 


\section{Opportunities and challenges for bioeconomy development}

Both case study regions contain a vast amount of renewable biological resources from the sea, forest and land currently managed and exploited in a rather traditional way. The traditional forestry and fishery industries play an important role in the regional economies. The bioeconomy offers opportunities to modernise and develop the existing industries further and create new ones by generating more value from the existing renewable biological resources through increased circularity and the application of innovative technologies. The lack of knowledge and insights into the bioeconomy represents a challenge for exploiting its full potential in Northwest Russia.

Nonetheless, there is clear evidence that the transition to a bioeconomy in Northwest Russia has already begun. Among the positive examples of this has been the increased attention to the utilisation of waste products and residues from the fisheries and forestry industries, as well as the increased processing of raw materials. Targeted support has been provided by the Federal Government to those private investors willing to make use of local waste streams and develop advanced and higher value-added products from the fisheries and forestry resources. Primarily large-scale investment projects appear to gain support, whereas that for small-scale initiatives and projects remains rather limited. The customs policy is another mechanism to stimulate the increased processing and utilisation of local raw materials, with higher (lower) export tariffs applied to less-(more-) processed and low (high) value-added products. However, the effects of these policies and measures on triggering bioeconomy development remain to be seen, as these are all rather recent incentives.

At the regional level, increased support to the bioeconomy is also evident. 'The Concept for Creating a Biotechnological Cluster in the Republic of Karelia' was developed under the framework of the regional law on the state support of biotechnological and food industries adopted in 2017. Among the strategic priorities outlined are the processing of wild plants and medicinal raw materials, and the increased processing and utilisation of aquatic bioresources and forest and wood industry wastes in the Republic of Karelia.

Economic sanctions have played an important role in boosting local production and have had an overall positive impact on bioeconomic sectors. As for aquaculture, it had been poorly incentivised and even neglected in Russia until the importreplacing policy was introduced in 2014 as a response to the sanctions. The Federal Government has allocated funding support to help businesses ease the burden of loans for the purchase of feed, modern equipment and investment into building a

\section{BOX 5. The impact of economic sanctions on the fisheries and forestry sectors}

In 2014, several Western countries introduced economic sanctions against Russia. In response, Russia prohibited the import of different goods, including fish and seafood from a number of countries, including Norway and those in the EU. One benefit was that Russian fishery companies captured a larger share of the local market. However, this also led to price escalation and limits in the choice of products for Russian consumers.

Neither the economic sanctions nor the import ban targeted the forestry sector. However, the forestry sector was affected by their indirect impact on the economy due to the weakening of the rouble and the decrease in investment. Given the current political and economic situations, foreign investors and trade partners are losing confidence in Russia. Nevertheless, exports of forestry sector products, particularly processed wood products, have been gradually increasing (Interfax, 2019). 
local production capacity for aquaculture. In the Republic of Karelia, significant investment support has recently been channelled to developing the entire value chain of aquaculture activities, including the local production of fish feed and fish breeding facilities, both of which are currently highly dependent on imports.

The economic opportunities associated with the development of a bioeconomy (e.g. job creation) is more pronounced in contemporary political discourse than the environment and climate change. This means that investment decisions are often motivated by economic benefits rather than environmental concerns. Insufficient attention to the environmental aspects of developing a bioeconomy may undermine its positive outcomes. Importantly, the bioeconomy is not sustainable per se, but requires a balanced approach that considers economic, social and environmental objectives. In the regions studied, the rapid development of aqvaculture has resulted in environmental pressure and degradation, as well as conflicts with the local population. In planning the further expansion of aquaculture activities, actions to secure the surrounding environment should be carefully considered.

This study revealed that there is a lack of development in new resilient energy systems for remote communities, and these remain dependent on imported fossil fuels (fuel oil and coal). For high forest cover regions such as the Republic of Karelia, the utilisation of woodchips and fuel-wood for heating should be further promoted as a way to reduce dependency on imported mineral fuel and achieve environmental benefits. Among the reasons for the low utilisation of locally available energy sources is the subsidisation of natural gas and its distribution networks (in case of the Republic of Karelia) and a lack of incentives for the forestry companies and municipal authorities to increase the utilisation of biofuels. Despite being a local resource, woodchips do not appear to be the cheapest option among other fuel alternatives. This calls for the development of an enabling public policy and the targeting of public subsidies favouring local renewable fuel sources above imported fossil fuels.

There is a rather strong educational and research environment in the regions, as well as available knowledge and expertise in the fields of biotechnology, fisheries and forestry. Despite a number of innovations and patented technolo- gies in the field of biotechnology, poor research commercialisation is a challenge (interview with research actors; Murmansk Vestnik, 2015). Improving business-academia co-operation and the business-relevance of research and education are crucial success factors for the development of a bioeconomy, as innovation and research are at the core of such a transition.

Although a bioeconomy may create new jobs and economic activities in and around rural areas, the shortage of employees (both low- and highskilled) could become a challenge. There is an acute shortage of the economically active part of the population against the background of a constant outflow of young people, the low level of qualifications of existing workers and the uneven distribution of educational resources in the territory of the regions studied. Moreover, the quality and attractiveness of education in traditional forestry and fishery-related fields is low, which may also hinder bioeconomy development in the future (interview with an industry representative).

The interaction between industry and education at all stages of the life cycle should be encouraged and improved to increase the relevance of research and education in regard to the needs of the industry and boost the attractiveness of bioeconomy-related jobs and education. This may require developing flexible educational programmes in co-operation with industry.

In the fisheries sector, several challenges have been identified in interviews with experts and from secondary sources. The lack of innovative and high value-added fish products in the share of production is one of these challenges. Boosting fish processing businesses to increase the utilization of fish wastes, diversify production and advance innovation are important priorities at both the federal and regional levels. In Murmansk oblast, there is a shortage of raw materials to meet the needs of these industries, the main reason being the small quota distribution to coastal fishery companies in the region (6\%), which limits their operations, as well as the high export orientation of oceanic fishery companies. This already places many coastal fishery and processing companies in the Murmansk region on the verge of bankruptcy.

The regional authorities have limited capacity to influence this situation. The regional actors in Murmansk stress that the Federal Government should take actions to regulate exports and the domestic price of fish, such as regulating customs 
tariffs. Moreover, policies protecting regional fish processing companies should be introduced (RG, 2018).

Another challenge for the fisheries sector is technologically outdated infrastructure (vessels and ports) and the sluggish pace of modernization. A programme supporting the modernisation of these assets is being implemented all across Russia. However, development is expensive and slow, and it might take many years for the results to be evident.

As mentioned above, aquaculture is a dynamically developing industry having a great potential to contribute to regional economies. The development of the entire value chain, including fish breeding, fish feed and the utilisation of fish wastes, will make the industry less dependent on imports and increase its value-added locally. At the same time, the environmental threats associated with aquaculture activities should not be overlooked. Conflicts with the local population already exist and may become even more common in the future with the expansion of these activities.

As to the forest-based bioeconomy, there is significant potential to create more value from biomass through biorefining activities. Concepts for biorefineries could be developed based on multiple sources (e.g. fish wastes, wood input, organic household wastes, manure), resulting in the better use of local waste streams, the development of new products, the production of feed for aquaculture, husbandry, energy, the creation of jobs, etc.

The construction of wooden houses is a fastdeveloping field in the forest-rich regions of Russia, including the Republic of Karelia. This can create new jobs, contribute to the improved utilization of local resources and provide better housing. A growing demand for wooden construction can be transferred into an investment in more sustainable forest management and the develop- ment of forest roads. According to the private sector actors interviewed, strategic support from the Federal Government is needed to boost wooden construction in Russia. The support could be provided to foster collaboration involving the state and research organisations to support the business models in wooden construction. Changes are also needed concerning the legislation and technical standards for the construction of wooden houses, based on discussions and expert contributions from the business and research community. These are important preconditions for businesses to be able to offer an efficient model for mass wooden construction that could meet the current demand of the construction market.

The use of other biological resources from forests such as berries and mushrooms for commercial purposes have gained considerable attention in the Republic of Karelia. The construction of a biorefinery that can use raw material to produce high value-added ingredients for the health industry is among the examples of emerging good practices of bioeconomic activities in the region. Gathering mushrooms and berries has traditionally been an important economic activity for rural residents as an additional, or in some cases, the only source of income. The bioeconomy offers opportunities to strengthen these activities further and develop new businesses around the use of renewable biological resources from forests that helps to develop value creation close to the source of origin.

Considering the increasing demand for authentic and environmentally-friendly products from nature (forest, land and marine environment), there is good potential for the development of niche products. Moreover, linkages and collaboration between the local food, culture and recreational and nature-based tourism industry could be further explored in the emerging bioeconomy. 


\section{References}

AIF Karelia (2017a) Nikolay Fedorenko: The life's dream dream is to have an environmentally friendly production (In Russian: Николай Федоренко: Мечта всей моей жизни экологически чистое производство). Available at: http://www.karel.aif.ru/society/ nikolay_fedorenko_mechta_vsey_moey_zhizni_-ekologicheski_chistoe_proizvodstvo (accessed 5 May 2019).

AIF Karelia (2017b) The profit is there where it is 'clean' (In Russian: Где чисто, там и прибыль). Available at: http://www.karel.aif.ru/society/ persona/gde_chisto_tam_i_pribyl (accessed 5 May 2019).

AIF Karelia (2019) Scandal on Sandal lake. Kondopozh residents oppose trout farming (In Russian: Скандал на Сандале. Кондопожане выступают против форелеводов).

Available at: http://www.karel.aif.ru/society/ details/skandal_na_sandale_kondopozhane_ vystupayut_protiv_forelevodov (accessed 5 May 2019).

Barentsinfo (2019) Administration in Russia - Barentsinfo. Available at: http:// www.barentsinfo.org/Barents-region/ Administration/Administration-in-Russia (accessed 29 April 2019).

Bellona (2018) Murmansk region aims to be the driver of Russia's e-car and renewable energy economy. Available at: https://bellona.org/ news/renewable-energy/2018-11-murmanskregion-aims-to-be-the-driver-of-russias-e-carand-renewable-energy-economy (accessed 23 April 2019).

Berlina A and Trubin A (2018) Bioeconomy in Northwest Russian region: Forest- and wastebased bioeconomy in the Arkhangelsk region, Russia. Available at: http://norden.diva-portal. org/smash/record.jsf?faces-redirect=true\&aq2= $\% 5 B \% 5 B \% 5 D \% 5 D \& a f=\% 5 B \% 5 D \&$ searchType= SIMPLE\&sortOrder2=title_sort_asc\&query=\&la nguage $=$ sv\&pid $=$ diva2\%3A $1210615 \& a q=\% 5 B \% 5$ $B \% 5 D \% 5 D \& s f=a l l \& a q e=\% 5 B \% 5 D \&$ sortOrder $=a$ uthor_sort_asc\&onlyFullText=false\&noOfRows= 50\&dswid=-21 (accessed 9 June 2019).

BezFormata (2019a) New boilers in Umba will operate on peat and wood waste (In Russian: Новые котельные в Умбе будут работать на торфе и отходах деревообработки). Available at: http://murmansk.bezformata. com/listnews/umbe-budut-rabotat-natorfe/72353806/ (accessed 18 April 2019).

BezFormata (2019b) Peat boilers in Umba will be operational by the end of 2019 (In Russian: Торфяные котельные в Умбе заработают к концу 2019 года). Available at: http://murmansk.bezformata.com/ listnews/torfyanie-kotelnie-v-umbezarabotayut/72320580/ (accessed 18 April 2019).

Bolatayeva A, Bulkayeva R and Dzhagayeva $V$ (2017) Tax system of the Russian Federation: Urgent problems and ways of improvement of modern tax system (In Russian: Налоговая система Российской Федерации: Актуальные проблемы и пути совершенствования современной налоговой системы). Nauchnie Izvestija 6. Available at: https://cyberleninka.ru/ article/v/nalogovaya-sistema-rossiyskoyfederatsii-aktualnye-problemy-i-putisovershenstvovaniya-sovremennoy-nalogovoysistemy (accessed 11 June 2019).

B-Port News (2019) The number of residents in TOD"Kirovsk" may double (In Russian: Количество резидентов в ТОСЭР «Кировск» может увеличиться в два раза). Available at: https://b-port.com/news/224650 (accessed 29 April 2019).

Customsonline (2019) Rates of customs duties on goods exported from the Russian Federation (In Russian: Изменение ставок таможенного тарифа с 1 января 2019 года при экспорте). Available at: http://customsonline.ru/tariff_ change_exp.html (accessed 12 June 2019).

Dzjubuk IM and Ryzhkov LP (2014) Growth of juvenile rainbow trout in the cage farms of Karelia (In Russian: Рост молоди радужной форели в садковых хозяйствах Карелии). Available at: https://cyberleninka.ru/article/v/ rost-molodi-raduzhnoy-foreli-v-sadkovyhhozyaystvah-karelii (accessed 5 May 2019).

FAO (2012) The Russian Federation Forest Sector Outlook Study to 2030. Rome: FAO.

Federal Law 131-FZ (2003) Federal law from 06.10.2003 N 131-FZ (as amended 
on 05/01/2019) Article 17 "On the general principles of the organization of local selfgovernment in the Russian Federation (In Russian: "Федеральный закон 'Об общих принципах организации местного самоуправления в Российской Федерации' (закон о МСУ) от 06.10.2003 N 131-Ф3). Available at: http://www.consultant.ru/ document/cons_doc_LAW_44571/ (accessed 11 June 2019).

Fish Portal (2017) An agreement on the launch of a plant producing pharmaceutics from fish waste was concluded in Murmansk. (In Russian: Соглашение о запуске завода сырья для лекарств из рыбных отходов заключили в Мурманске). Available at: https://www. fish-product.ru/news/soglashenie-o-zapuskezavoda-syrya-dlya-lekarstv-iz-rybnyhothodov-zaklyuchili-v-murmanske-8715 (accessed 25 April 2019).

Forestry School (2019) Shuisko-Vidanskaya Forestry School (In Russian: ШуйскоВиданская лесотехническая школа). Available at: http://www.lth.vlesprome.ru/ (accessed 5 June 2019).

FSC (2018) Certification system of FSC Controlled Wood in Forest Management (CW/ FM). Available at: http://en.fcert.ru/services/ certification_services/cw_fm/ (accessed 4 June 2019).

FSC (2019) FSC CERTIFICATION. Available at: https://ic.fsc.org/en/what-is-fsc-certification (accessed 4 June 2019).

Gerden E (2018) Grin and Barents: Russian Aquaculture looks to lucrative times ahead. Available at: https://thefishsite.com/articles/ grin-and-barents-russian-aquaculture-looksto-lucrative-times-ahead (accessed 25 April 2019).

Glushkov A (2017) Investment projects in the Murmansk Region. Kemi, Finland.

Gosjkh (2019) Emergency housing in Murmansk (In Russian: Аварийные дома в Мурманске). Available at: http://gosjkh.ru/ehouses/ murmanskaya-oblast/murmansk (accessed 12 June 2019).

Government (2019) National project 'Housing and urban environment' (In Russian: Национальный проект «Жильё и городская среда). Available at: http://government.ru/ projects/selection/735/35560/ (accessed 12 June 2019).
Government of Murmansk oblast (2013) September 30, 2013 N 561-חП THE APPROVAL OF THE STATE PROGRAMME OF THE MURMANSK REGION 'DEVELOPMENT OF THE FISHERIES COMPLEX' (In Russian:Постановление от 30 сентября 2013 г. N 561-ПП ОБ УТВЕРЖДЕНИИ ГОСУДАРСТВЕННОЙ ПРОГРАММЫ МУРМАНСКОЙ ОБЛАСТИ 'РАЗВИТИЕ РЫБОХОЗЯЙСТВЕННОГО КОМПЛЕКСА'.

Government of Murmansk oblast (2018) In Umba, the construction of boilers operating with the use of peat is ongoing in accordance with the terms stipulated by the concession agreement (In Russian: В Умбе строительство котельных, работающих с использование торфа, осуществляется в соответствии со сроками, предусмотренными концессионным соглашением). Available at: https://gov-murman.ru/info/news/267634/ (accessed 18 April 2019).

Helion Ltd (2018) Report of the Ministry of Fisheries and Agriculture of the Murmansk region (In Russian: Отчет министерства рыбного и сельского хозяйства Мурманской области). Available at: https://helion-ltd.ru/ news/23245-otchet-ministerstva-rybnogo-iselskogo-hozyaystva-murmanskoy-oblasti/ (accessed 24 April 2019).

Hibiny (2018a) The authorities of the Murmansk region will continue to seek gasification of the region (In Russian: Власти Мурманской области продолжат добиваться газификации региона). Available at: https:// www.hibiny.com/news/archive/164600/ (accessed 18 April 2019).

Hibiny (2018b) The construction of four solid fuel boilers in Umba is on schedule (In Russian: Строительство четырех твердотопливных котельных в Умбе идет по графику). Available at: https://www.hibiny.com/news/ archive/173865/ (accessed 18 April 2019).

Jóhannesson $\mathrm{H}$ and Sigfusson $\mathrm{T}$ (2018) The Russian Seafood Modernization: A Message from Russia. Iceland Ocean Cluster. Available at: http://www.sjavarklasinn.is/wp-content/ uploads/2018/11/AF_Russia.pdf.

Kareliainvest (2013) Law of the Republic of Karelia of 05.03.2013 N 1687-ZRK "On state support of investment activities in the Republic of Karelia (In Russian: Закон Республики Карелия от 05.03.2013 N 
1687-3РК «О государственной поддержке инвестиционной деятельности в

Республике Карелия»). Available at: http:// kareliainvest.ru/investitsionnyy-klimatregiona/invest-politika/normativnye-pravovyeakty/ (accessed 4 May 2019).

Kareliainvest (2016a) About the region (In Russian: О регионе). Available at: http:// kareliainvest.ru/investitsionnyy-klimatregiona/o-regione/ (accessed 4 May 2019).

Kareliainvest (2016b) Territory of advanced social and economic development 'Kondopoga' (In Russian: Территория опережающего социально-

экономического развития «Кондопога»). Available at: http://kareliainvest.ru/acts/ territoriya-operezhayushchego-sotsialnoekonomicheskogo-razvitiya-kondopoga/ (accessed 1 May 2019).

Kareliainvest (2016c) The territory of advanced social and economic development 'Nadvoitsy'. The Industrial Park 'Nadvoitsy' (In Russian: Территория опережающего социальноэкономического развития «Надвоицы». Промышленный парк «Надвоицы»). Available at: http://kareliainvest.ru/acts/ territoriya-operezhayushchego-sotsialnoekonomicheskogo-razvitiya-nadvoitsy/ (accessed 1 May 2019).

Kareliainvest (2018) Investment passport of the Republic of Karelia (In Russian: Инвестиционный паспорт Карелия). Available at: http://kareliainvest.ru/ investitsionnyy-klimat-regiona/\%D0\%98\% DO\%BD\%DO\%B2\%DO\%B5\%D1\%81\%D1\% 82\%D0\%B8\%D1\%86\%D0\%B8\%D०\%BE\% DO\%BD\%D0\%BD\%D1\%8B\%D0\%B9\%20 \%D0\%BF\%D0\%B0\%D1\%81\%D0\%BF\%DO\%BE\%D1\%80\%D1\%82\%20\%D0\%9A\%D0\%B O\%D1\%80\%D0\%B5\%D0\%BB\%D0\%B8\%D1 $\% 8$ F.pdf.

Kareliainvest (2019a) Pulp and paper industry (In Russian: Целлюлозно-бумажная промышленность). Available at: http:// kareliainvest.ru/republic-for-investors/ projects/tsellyulozno-bumazhnayapromyshlennost/ (accessed 1 May 2019).

Kareliainvest (2019b) Woodworking industries (In Russian: Древообрабатывающая промышленность). Available at: http:// kareliainvest.ru/republic-for-investors/ projects/drevoobrabatyvayushchaya- promyshlennost/ (accessed 1 May 2019).

Kareliastat (2019) The Republic of Karelia in figures 2019 (In Russian: РЕСПУБЛИКА КАРЕЛИЯ В ЦИФРАХ' 2019. Краткий статистический сборник). Available at: http://krl.gks.ru/wps/wcm/ connect/rosstat_ts $/ \mathrm{krl} /$ resources/ ff10b880488c910dbcb8fcf7eaa5adf2/02471. pdf.

Karelinform (2018a) A new fish oil production plant will be built in Karelia (In Russian: Новый цех по производству рыбьего жира откроют в Карелии). Available at: https:// karelinform.ru/news/economy/31-10-2018/ novyy-tseh-po-proizvodstvu-rybiego-zhiraotkroyut-v-karelii (accessed 5 May 2019).

Karelinform (2018b) Where does the Karelian trout go? (In Russian: Куда плывет карельская форель?). Available at: https:// karelinform.ru/article/general/23-01-2018/ kuda-plyvet-karelskaya-forel-00afe9bf-b2894e97-945d-bc91a7ce0879 (accessed 5 May 2019).

Kortelainen J and Nystén-Haarala S (2016)

Construction of Trust in Russian Mill Towns (In: The Changing Governance of Renewable Natural Resources in Northwest Russia). Available at: https://play.google. com/books/reader?id=kG3eCwAAQBA $J \& h l=s v \&$ printsec=frontcover\&pg $=$ GBS. PT181\#v=onepage \&q=governance $\% 20$ of $\% 20$ fish\%2Oresources\%20russia\&f=false (accessed 26 April 2019).

Kostrov V (2018) Fisheries in the Murmansk region on the verge of a catastrophe: 'We cannot survive this way' In Russian (Рыбный промысел в Мурманской области на пороге катастрофы: «Так дальше жить нельзя»). Available at: https://www. murmansk.kp.ru/daily/26897.7/3941620/ (accessed 26 April 2019).

Lesprominform (2014) Karelia is gradually converting boiler houses to pellets and chips (In Russian: Карелия постепенно переводит котельные на пеллеты и щепу). Available at: https://lesprominform.ru/news.html?id=5758 (accessed 6 May 2019).

Ministry of Fisheries and Agriculture of Murmansk region (2018) Ministry of Fisheries and Agriculture of Murmansk region- Results 2017. (In Russian: Фактические результаты | Министерство рыбного и сельского 
хозяйства Мурманской области). Available at: http://mrcx.gov-murman.ru/about/results/ fact/ (accessed 24 April 2019).

Ministry of Natural Resources and Ecology of Murmansk oblast (2019) Forest plan of Murmansk oblast (in Russian: Лесной план Мурманской области). Available at: https:// mpr.gov-murman.ru/documents/lesplan/ (accessed 17 April 2019).

Ministry of Natural Resources and Ecology of the Republic of Karelia (2016) Measures of state support for forestry enterprises (In Russian: Меры государственной поддержки предприятий ЛПК). Available at: https:// minprirody.karelia.ru/lesopromyshlennyjkompleks/mery-gosudarstvennoj-podderzhkipredprijatij-lpk/ (accessed 1 May 2019).

MSTU (2019) Murmansk State Technical University. Available at: http://eng.mstu.edu. ru/ (accessed 8 June 2019).

Murmansk Arctic State University (2019) Murmansk Arctic State University. Available at: http://www.masu.edu.ru/ (accessed 8 June 2019).

Murmansk Marine Fisheries College (2019) Murmansk Marine Fisheries College. Available at: http://mmrc.mstu.edu.ru/ (accessed 8 June 2019).

Murmansk Vestnik (2015) Bioeconomy as a requirement of the century (In Russian: Биоэкономика как требование века). Available at: https://www.mvestnik.ru/ economy/pid201501298l/ (accessed 25 April 2019).

Murmanskstat (2019) Construction sector. Available at: http://murmanskstat.gks.ru/wps/ wcm/connect/rosstat_ts/murmanskstat/ru/ statistics/enterprises/construction/ (accessed 12 June 2019).

Nalog (2019) The tax system of the Russian Federation: the concept, elements and structure (In Russian: Налоговая система РФ: понятие, элементы и структура). Available at: https://nalog-nalog.ru/ nalogovaya_sistema_rf/nalogovaya_sistema_ rf_ponyatie_elementy_i_struktura/ (accessed 11 June 2019).

Nevski News (2018) Fish waste processing plant to be built in Karelia (In Russian: В Карелии появится завод по переработке рыбных отходов). Available at: //nevnov.ru/region/ Petrozavodsk/539733-v-karelii-poyavitsya- zavod-po-pererabotke-rybnykh-otkhodov (accessed 5 May 2019).

Northwest Marine Business (2018) We've got fish. Next step is the fleet. (In Russian: Рыба есть. Дело за флотом). Available at: http://mbsz. ru/?p=29946 (accessed 25 April 2019).

Nysten-Haarala S and Kotilainen J (2016) Institutions, Interest Groups and Governance of Natural Resources in Russia. (In: The Changing Governance of Renewable Natural Resources in Northwest Russia). Routledge.

OECD (2016) Russian Federation. Basic socioeconomic indicators. Available at: https://www. oecd.org/regional/regional-policy/profileRussian-Federation.pdf.

Pappila M (2016) Russian Forest Regulation and the Integration of Sustainable Forest Management (in: The Changing Governance of Renewable Natural Resources in Northwest Russia). Routledge.

Petrozavodsk Forestry College (2019) Petrozavodsk Forestry College (In Russian: Петрозаводский лесотехнический техникум). Available at: http://lesteh10.ru/ uchebnaya/speciality/ (accessed 5 June 2019).

PetrSU (2019) Petrozavodsk State University (In Russian: Петрозаводский государственный университет). Available at: https://petrsu.ru/ page/education/bakalavriat_i_spec (accessed 5 June 2019).

PWC (2014) Guide to Investment: Republic of Karelia. Available at: https://www.pwc.ru/en/ doing-business-in-russia/assets/pwc_invest_ karelia-eng.pdf.

Refsgaard, K., Teräs, J., Kull, M., Oddsson, G., Jóhannesson, T. and Kristensen, I. (2018). The rapidly developing Nordic bioeconomy. In Grunfelder, J., Rispling, L. and Norlén, G. (eds.) State of the Nordic Region 2018. 13 February. Available at: http://www.nordregio.org/ publications/state-of-the-nordic-region-2018/ (accessed 9 June 2019).

Resolution 310 (2007) Resolution $\mathrm{nr} 310$ on the rates for the unit of the forest area in federal ownership (In Russian: Постановление Правительства РФ от 22.05.2007 N 310 (ред. от 20.02.2019). Available at: https:// rulaws.ru/goverment/PostanovleniePravitelstva-RF-ot-22.05.2007-N-310/ (accessed 11 June 2019). 
RG (2003) Local Government Act (In Russian: Закон о местном самоуправлении). Available at: https://rg.ru/2003/10/08/ zakonsamouprav.html (accessed 11 June 2019).

RG (2018) On a diet. Fish prices in the Murmansk region continues to increase (In Russian: Рыба в Мурманской области продолжает дорожать). Available at: https://rg.ru/2018/10/02/reg-szfo/ryba-vmurmanskoj-oblasti-prodolzhaet-dorozhat. html (accessed 7 June 2019).

RIA News (2018a) Kovtun: the development of the Murmansk region is impossible without gasification (In Russian: Ковтун: прорывное развитие Мурманской области невозможно без газификации). Available at: https://ria.ru/20180418/1518974021.html (accessed 22 April 2019).

RIA News (2018b) The procedure for the election of governors in Russia (In Russian: Процедура выборов губернаторов в России). Available at: https://ria.ru/20180923/1528970946.html (accessed 11 June 2019).

Rosstat (2017) Russia in Figures 2017. Available at: http://www.gks.ru/free_doc/doc_2017/rusfig/ rus17e.pdf.

Rosstat (2018) Regions of Russia: Social Economic indicators. Available at: http://www. gks.ru/wps/wcm/connect/rosstat_main/ rosstat/ru/statistics/publications/catalog/ doc_1138623506156 (accessed 17 April 2019).

Russia Beyond (2016) Swimming against the tide: Russia's trout industry takes off. Available at: https://www.rbth.com/business/2016/11/25/ swimming-against-the-tide-russias-troutindustry-takes-off_651017 (accessed 5 May 2019).

Russian Export (2019) Export from Karelia increased by $12.6 \%$ in 2019 (In Russian: Карельский экспорт вырос на 12,6\% в 2019 году). Available at: http://www.rusexporter.ru/ news/

Shcherbak A and Tishkov S (2014) Ecology of the fish industry in the Republic of Karelia. Energy and Ecology (Альтернативная энергетика и экология in Russian) 15(155).

Staalesen A (2015) Fish on fire. Available at: https://thebarentsobserver.com/en/2015/11/ salmon-fire (accessed 25 April 2019).

Staalesen A (2017) Fishy business on Murmansk waterfront. Available at: https:// thebarentsobserver.com/en/industry-and- energy/2017/01/fishy-business-murmanskwaterfront (accessed 25 April 2019).

Sterligova OP, Kitaev SP and Ilmast NV (2008) The State of North Karelia lakes and their use for commodity production of rainbow trout. Available at: https://cyberleninka.ru/article/v/ sostoyanie-nekotoryh-vodoemov-severnoykarelii-i-ih-ispolzovanie-dlya-tovarnogovyraschivaniya-raduzhnoy-foreli-1 (accessed 5 May 2019).

Stolica Onego (2019) A fish breeding center will be built in the north of Karelia in 2019 (In Russian: Центр рыбоводства начнут строить на севере Карелии в 2019 году). Available at: https://stolicaonego.ru/news/ tsentr-rybovodstva-nachnut-stroit-na-severekarelii-v-2019-godu/ (accessed 5 May 2019).

Stupachenko I (2018a) Private fishing firms step up to invest in Russia's ports. Available at: https://www.seafoodsource.com/features/ private-fishing-firms-step-up-to-invest-inrussia-s-ports (accessed 25 April 2019).

Stupachenko I (2018b) Russia tackling ambitious modernization plan for its seafood sector. Available at: https://www.seafoodsource. com/features/russia-tackling-ambitiousmodernization-plan-for-its-seafood-sector (accessed 25 April 2019).

The Constitution of the Russian Federation (2001) Chapter 5. The Federal Assembly. The Constitution of the Russian Federation. Available at: http://www.constitution.ru/ en/10003000-06.htm (accessed 11 June 2019).

The Ministry of Natural Resources and Ecology of the Republic of Karelia (2019) Information about the forests of the Republic of Karelia (In Russian: Информация о лесах Республики Карелия). Available at: https://minprirody. karelia.ru/lesnoe-hozjajstvo/informacija-olesah-respubliki-karelija/ (accessed 30 April 2019).

The Republic (2019) Stepashin approved the construction of wooden frame houses in the framework of the emergency room resettlement program (In Russian: Степашин одобрил строительство деревянных каркасных домов по программе расселения "аварийки» ). Available at: http://rk.karelia.ru/ekonomika/production/ stepashin-odobril-stroitelstvo-derevyannyhkarkasnyh-domov-po-programme-rasseleniyaavarijki/ (accessed 6 June 2019). 
The Republic of Karelia (2014) The Republic of Karelia (brief information). Available at: http:// old.gov.karelia.ru/gov/Different/karelia3_e. html (accessed 29 April 2019).

The Republic of Karelia (2018) Karelia to be free from wood wastes (In Russian: Карелию предлагают очистить от древесных отходов). Available at: http://old.gov.karelia. ru/gov/News/2018/10/1018_16.html (accessed 3 June 2019).

The Republic of Karelia (2019a) Arthur Parfenchikov approved a new program of relocation from emergency housing (In Russian: Артур Парфенчиков утвердил новую программу переселения из аварийного жилья). Available at: http://gov.karelia. ru/news/O2-04-2019-artur-parfenchikovutverdil-novuyu-programmu-pereseleniya-izavariynogo-zhilya/ (accessed 6 June 2019).

The Republic of Karelia (2019b) The strategy for the development of the forest industry complex in the Republic of Karelia until 2030 has been approved (In Russian: Утверждена Стратегия развития лесного комплекса Карелии до 2030 года). Available at: https:// proderevo.net/news/indst/utverzhdenastrategiya-razvitiya-lesnogo-kompleksakarelii-do-2030-goda.html (accessed 4 May 2019).

The Russian Government (2018a)

About the development of fish processing industry (in Russian: $\mathrm{O}$ развитии рыбоперерабатывающей промышленности). Available at: http:// government.ru/news/32356/ (accessed 24 April 2019).

The Russian Government (2018b) About the priority investment projects in the field of forest development (In Russian: $O$ приоритетных инвестиционных проектах в области освоения лесов). Available at: http://government.ru/docs/31510/ (accessed 5 June 2019).

The Russian Government (2018c) Approval of the Forestry Development Strategy until 2030 (In Russian: Об утверждении Стратегии развития лесного комплекса до 2030 года). Available at: http://government.ru/ docs/34064/ (accessed 5 June 2019).

Vassiljev A (2018) Fish industry of the Murmansk region in numbers (In Russian: Рыбная отрасль Мурманской области в цифрах). Available at: https://goarctic.ru/work/ rybnaya-otrasl-murmanskoy-oblasti-vtsifrakh/ (accessed 24 April 2019).

Votinova E and Votinov M (2017) Assessment of the current state of the fishing industry: a statistical overview and analysis of the situation (In Russian: Оценка современного состояния рыбной промышленности: статистический обзор и анализ ситуации). Vestnik AGTU. Economics 2.

What Wood (2019) In Karelia for the implementation of five priority projects in the field of forest development invested 11 billion rubles. Available at: http://whatwood.ru/ english/in-karelia-for-the-implementationof-five-priority-projects-in-the-field-offorest-development-invested-11-billion-rubles/ (accessed 4 May 2019).

WWF Russia (2015) An Integrated Environmental Management Plan for the Russian Part of the Barents Sea (In Russian: Комплексное управление ресурсами Баренцева Моря). Available at: https://wwf.ru/regions/thebarents-branch/kompleksnoe-upravlenieresursami-barentseva-morya/ (accessed 26 April 2019).

WWF Russia (2017) Nothern Fishermen Continue Industry Greening. Available at: https://wwf. ru/en/resources/news/morya/zapolyarnyerybaki-prodolzhayut-rabotu-po-ekologizatsiipromysla/ (accessed 23 April 2019). 


\section{Appendix 1. List of interviewees}

\section{Republic of Karelia}

\begin{tabular}{|c|c|c|}
\hline Name & Organisation & Date \\
\hline Yuri Saveljev & $\begin{array}{l}\text { The Corporation of Development of the Republic of } \\
\text { Karelia }\end{array}$ & 2 August 2018 \\
\hline Sergei Dubinin & The Karelian Business Centre & 2 August 2018 \\
\hline \multirow[t]{2}{*}{ Anatali Rekunov } & Zagotprom (a private company) & 2 August 2018 \\
\hline & $\begin{array}{l}\text { The Ministry of Natural Resources and Environment of } \\
\text { the Republic of Karelia }\end{array}$ & 2 August 2018 \\
\hline Alexander Berdino & ANO Energy Efficiency Centre & 3 August 2018 \\
\hline $\begin{array}{l}\text { Anton Shcherbak } \\
\text { A. Tishkov } \\
\text { Alexey Pekkoev } \\
\text { N. Galibina }\end{array}$ & $\begin{array}{l}\text { The Karelian Research Centre of the Russian Academy } \\
\text { of Sciences }\end{array}$ & 3 August 2018 \\
\hline Sergey Filin & Aquaculture expert & October 2018 \\
\hline Alexander Beljaev & Nord-Ost Rybprom fish farming enterprise & October 2018 \\
\hline
\end{tabular}

\section{Murmansk oblast}

\begin{tabular}{|c|c|c|}
\hline Name & Organisation & Date \\
\hline Vadim Ulanov & The Corporation of Development of Murmansk oblast & 30 July 2018 \\
\hline Anna Kireeva & Bellona & 30 July 2018 \\
\hline Vitaly Akimov & $\begin{array}{l}\text { The Chamber of Commerce and Industry of the } \\
\text { Murmansk region }\end{array}$ & 31 July 2018 \\
\hline Yulia Giljarova & $\begin{array}{l}\text { Kola Scientific Centre of the Russian Academy of } \\
\text { Sciences }\end{array}$ & 31 July 2018 \\
\hline Irina Tsvetkova & $\begin{array}{l}\text { The Ministry of Natural Resources and Ecology of } \\
\text { Murmansk oblast }\end{array}$ & 31 July 2018 \\
\hline Alexander Evseenko & Kolski forestry district & 31 July 2018 \\
\hline Alexander Dvorjankin & Priroda DOZ forestry enterprise & 31 July 2018 \\
\hline Sergei Kemeisho & Biomarin (private company - fish) & November 2018 \\
\hline
\end{tabular}




\section{(1I) Nordregio}

P.O. Box 1658

SE-111 86 Stockholm, Sweden

nordregio@nordregio.org

www.nordregio.org

www.norden.org

ISBN: 978-91-87295-76-8

ISSN: 1403-2503

DOI: doi.org/10.30689/R2019:10.1403-2503 